ISSN: 0213-2079 - ISSN electrónico: 2386-3889

DOI: https://doi.org/10.14201/shhmo2016382237285

\title{
«A LA SOMBRA» DE HOMBRES AUSENTES: MUJERES MALCASADAS EN EL MUNDO HISPÁNICO DEL SETECIENTOS
}

\section{"In the Shadow» of Absent Men: Unhappily Married Women in the Hispanic World of the Seventeenth Century}

\author{
María José de la PASCUA SÁNCHEZ \\ Universidad de Cádiz \\ Correo-e: mariajose.pascua@uca.es
}

RESUMEN: Los hogares con jefatura femenina han ido perfilándose en investigaciones recientes como una realidad social significativa en la Europa del Antiguo Régimen. Bajo la dirección de una viuda frecuentemente y, en menor medida, de una soltera o una malcasada, el análisis de estas familias de mujeres solas ha permitido a los historiadores observar la vida de las mujeres desde los márgenes de las estructuras de poder patriarcal. La realidad económica, social y afectiva de malcasadas y casadas con marido ausente se halla necesitada de un análisis en profundidad que, más allá de su magnitud cuantitativa, afronte el desafío de imaginar a estas mujeres en unas circunstancias que, a simple vista, no superaban la cualidad de excepcional y fortuita, pero que en la práctica podrían haber conformado un espacio de autonomía y empoderamiento. En el presente estudio, documentación judicial y testamentaria referida al Cádiz de los últimos años del siglo XVII y del siglo XVIII es utilizada para componer diferentes trayectorias de vida de mujeres con maridos ausentes. Estos testimonios confirman que las experiencias de estas mujeres y la percepción de sí mismas difiere no solo en función de sus propias circunstancias, sino también de acuerdo con las fuentes que consideremos. Si de las denuncias de abandono de las «Requisitorias a Indias» puede deducirse para el colectivo unas condiciones generales de 
MARÍA JOSÉ DE LA PASCUA SÁNCHEZ

«A LA SOMBRA» DE HOMBRES AUSENTES:

MUJERES MALCASADAS EN EL MUNDO HISPÁNICO DEL SETECIENTOS

pobreza y dificultad, los testamentos ofrecen la visión de vidas completas donde el trabajo y los afectos se revelan como ejes básicos estructurantes.

Palabras clave: mujeres malcasadas; mujeres solas; mujeres, familia y trabajo; requisitorias a Indias; testamentos y relatos de vida; mundo hispánico; siglo XVIII; historia moderna.

ABSTRACT: The households with feminine heads have been revealed in recent research as an important social reality in Early Modern Europe. These households, often under direction of a widow, and to a lesser extent, of a spinster or an unhappily married woman, are providing historians with the possibility to observe women's lives from the margins of structures of patriarchal power. The economic, social and affective reality of unhappily married women needs a profound analysis, that goes beyond a quantitative magnitude, facing the challenge of imagining these women in conditions that, at first glance, didn't go beyond exceptional and accidental, but in reality they could have formed an environment of autonomy and power for themselves. In this study, judicial records and testaments which come from Cadiz in the Sixteenth and Seventeenth Centuries are utilised to show the different paths of the lifes of women with absent husbands. These testimonials confirm that the experiences of women and their own perception of themselves differ not only as a function of their own circumstances but also according to the sources that we could choose. If from the allegations of abandonment from the «Warrants to Indies» it can be deduced that for this collective, overall they experienced poverty and difficult conditions, their wills offer a visión of full lives where work and affection are basic structures.

Key words: Unhappily Married Women; Women Alone; Women, Work and Family; Warrants to West Indies; Wills and Life stories; The Hispanic World; Seventeenth Century; Early Modern History.

Malcasadas y mujeres con maridos ausentes constituyeron un colectivo socialmente significativo durante la Edad Moderna. Su rastro en las fuentes quedó asociado a la consideración de «mujeres solas», mujeres que no vivían bajo la tutela de un hombre y que desde los fundamentos de una sociedad patriarcal, donde la mujer se definía desde su relación de dependencia respecto a aquel, ocupaban una posición antinatural. La mirada usual de la sociedad sobre ellas osciló entre la lástima y la sospecha de un comportamiento transgresor; una mirada, en definitiva,

(C) Ediciones Universidad de Salamanca / ®@ Stud. his., H. ${ }^{a}$ mod., 38, n. 2 (2016), pp. 237-285 
de inquietud. A pesar de las dificultades de supervivencia y de esta mirada de sospecha, precisamente, el vacío de normas -jurídicas, religiosas, culturales- respecto a la condición de mujer sola: vacío de modelos de referencia suministrados por el poder, de marcos explicativos, incluso de un lenguaje simbólico para nombrar la situación, permitió a las mujeres decidir y experimentar con su vida. La utilización del concepto de «mujeres solas» aspira a re-orientar el análisis precisamente en esta segunda perspectiva, hacia la potencialidad de su situación de no dependencia como punto de arranque para una agencia más autónoma ${ }^{1}$.

El encuentro con los procesos históricos de construcción de identidades subjetivadas protagonizados por mujeres, y especialmente cuando estas forman parte de grupos socialmente desfavorecidos, ha tenido que esperar hasta décadas recientes. Desde la lógica tradicional, la situación de mujeres viudas, malcasadas o solteras, tenía, hasta hace muy poco, un tratamiento historiográfico parcial cuando no estaba ausente de los objetivos de los historiadores. Incluidas en el cajón de sastre de los grupos marginados (gentes de recursos limitados, con dificultades de supervivencia, sin hogar o en hogares desestructurados y abocados a la miseria, la mendicidad y la prostitución), es decir, en espacios económicos, sociales y culturales, al margen, formaban esa gran bolsa de «víctimas» cuya situación y condiciones de vida serpenteaba desde la pauperización a la pobreza solemne y de esta a la mendicidad y a la marginalidad. La adscripción general de las mujeres «solas» al grupo de los marginados, con escasos perfiles identitarios -individualizados- salvo la omnipresencia del género en los estudios realizados a partir de mediados de los 80 , continuaba y comprendía, por su parte, la opinión otorgada en épocas históricas anteriores, específicamente en los siglos XVI-XIX. Es decir, partía de un prejuicio de género para constituir una categoría, clasificatoria sin más, que definía a las mujeres y sus prácticas, por defecto y de forma previa al análisis. Las "pobres mujeres solas» que aparecían en los padrones, vecindarios y recuentos de población de aquellos siglos, y en las que la pobreza se manifestaba propiamente como causa de no estar bajo el cuidado de un hombre, seguirán siendo durante bastante tiempo las «pobres mujeres» del análisis histórico. En estas circunstancias el primer trabajo fue problematizar esa categoría y eso no se realizó desde la demografía, por mucho que los estudios de demografía histórica hayan hecho visibles a las mujeres solas (principalmente en su identificación con mujeres solteras y viudas) sino desde la historia social, y sobre todo desde la historia de las mujeres donde la perspectiva de análisis de las mujeres solas,

1. Pascua, M. J. J. de la: «Women Alone in Enlightenment Spain», en Jaffe, C., Lewis, E. (Eds.): Eve's Enlightenment: Women's Experience in Spain and Spanish America, 1726-1839. Baton Rouge, Louisiana State University Press, 2009, pp. 128-142. 
MARÍA JOSÉ DE LA PASCUA SÁNCHEZ

«A LA SOMBRA» DE HOMBRES AUSENTES:

MUJERES MALCASADAS EN EL MUNDO HISPÁNICO DEL SETECIENTOS

como la de las mujeres en general, se ha ido complejizando paulatinamente. Las investigaciones sobre la pobreza y la asistencia social -en los que la presencia de las mujeres viudas y malcasadas era destacable ${ }^{2}-$, ampliaron la óptica de análisis, encaminando el estudio de las mujeres solas hacia la historia social e insistiendo en que la soledad no era tanto un estado, biológico o civil, cuanto una experiencia que involucró a mujeres solteras, viudas o separadas. En ellas se trascendió una perspectiva analítica excesivamente orientada hacia la problemática demográfica, planteándose cuestiones como el significado del estatus de mujer sola o las implicaciones políticas, sociales y económicas del mismo en las sociedades patriarcales medieval y moderna. No estamos pues ante el descubrimiento de un sujeto único y las primeras recopilaciones ${ }^{3}$, advirtieron con datos concretos de los riesgos de considerar al grupo como colectivo homogéneo, tratado por los poderes públicos como tal y objeto de una única política, ni siquiera cuando se trataba de zonas próximas geográficamente y con características socioeconómicas afines. Las sospechas y precauciones que las autoridades toman respecto a ellas en algunas zonas de la Alemania del siglo $\mathrm{XvI}^{4}$, que vienen precedidas de reclamaciones realizadas durante el Xv por mujeres que quieren mantener ciertas libertades tradicionales $\mathrm{e}$ independencia de sus maridos ${ }^{5}$ y seguidas por otras tantas ante el reforzamiento de las estructuras patriarcales a lo largo del $\mathrm{XvI}^{6}$, constituyen un ejemplo de esas necesarias matizaciones.

No obstante, aunque el encuentro de los historiadores demógrafos con las mujeres solas fue en un principio meramente cuantitativo, tuvo el efecto positivo de acercarnos a un colectivo con una presencia relativa significativa en las sociedades occidentales del A. Régimen y también a unas fuentes que proporcionaban items válidos para un primer análisis de los subgrupos que lo integraban. Se suele establecer como media para la Europa Occidental una media en torno al 30 por ciento de hogares con jefatura femenina que, obviamente, esconde diferencias geográficas y temporales, pero también se viene insistiendo en los cambios que las circunstancias

2. Davis, N. Z.: Sociedad y cultura en la Francia moderna. Barcelona, Crítica, 1993, esp. cap. «Socorro a los pobres».

3. Bennett, J. M., Froide, A. M. (Eds.): Singlewomen in European Past, 1250-1800. Filadelfia, University of Pennsylvania Press, 1999.

4. Wiesner, M. E.: «Paternalism in Practice: the Control of Servants and Prostitutes in Early Modern German Cities», en BeBB, Ph. N., MARshall, S. (Eds.): The process of Change in Early Modern Europe. Athens, Ohio University Press, 1988, pp. 179-200.

5. Matrician, M.: "Women's Legal Conflicts in Fifteenth Century Germany», Women, Family, Private Life and Sexuality, Conference of the International Federation for Research in Women's History. Paper Abstracts. Queen's University Belfast (agosto, 2003).

6. Rowlands, A.: «To Wear a Virgin's Wreath: Gender and Problems of Conformity in Early Modern Germany», European Review of History, 1, 1994, pp. 227-234.

(C) Ediciones Universidad de Salamanca / ®®@ Stud. his., H. ${ }^{a}$ mod., 38, n. 2 (2016), pp. 237-285 
MARÍA JOSÉ DE LA PASCUA SÁNCHEZ

«A LA SOMBRA» DE HOMBRES AUSENTES:

MUJERES MALCASADAS EN EL MUNDO HISPÁNICO DEL SETECIENTOS

personales introdujeron en la vida individual de muchas mujeres y que conllevaron cambios de estado civil y diferentes situaciones vitales más o menos temporales marcadas por la soledad. La atención se centró primeramente en la importancia del celibato como característica específica del sistema demográfico europeo, para pasar a poner el acento en la significación del celibato y de la viudedad como itinerarios de soledad femenina frecuentes en las sociedades del Antiguo Régimen. No obstante, la ubicación, en los primeros estudios, de estas mujeres en un estado social marcado eminentemente por sus posibilidades reproductivas y por su edad biológica-noción de ciclo de vida-, dada la propia lógica de la mayoría de las fuentes utilizadas para estudiarlas, tuvo el efecto perverso de desindividualizarlas. Aun así fue produciéndose la visibilización de dos grandes grupos de mujeres solas dentro del colectivo: las viudas y las solteras, apareciendo las malcasadas y casadas con marido ausente como un subgrupo menor, cuantitativamente hablando. Su inferior peso cuantitativo y la ausencia de precisión en muchas fuentes sobre la condición de separada o malcasadas, motivó que ni siquiera para aquellas zonas, fundamentalmente urbanas, para las que se contaba con información precisa sobre el número de hogares con jefatura femenina, hallamos contado con conocimiento preciso de cuántos de esos hogares correspondían a mujeres casadas responsables de ellas mismas o de sus familias por ausencia de su esposo o por separación. Sin embargo, la jefatura de hogar femenina aparece significativamente en poblaciones poblaciones donde la emigración masculina era importante, situación que afectaba, sin duda, a la realidad cotidiana de estas mujeres. Bien porque no tuvieran más remedio que demandar más trabajo para sobrevivir y mantener a su familia, asumir la responsabilidad directa sobre el negocio familiar, administrar los bienes de la familia o constituir un negocio propio, bien porque la demanda se reorientara hacia la mano de obra femenina ante el descenso de trabajadores masculinos, el contexto fue propicio para un cambio en la relación de estas mujeres con el mundo del trabajo y el incremento de mujeres no dependientes y/o responsables de sus hogares. Pero no fue solo la necesidad de sobrevivir y mantener a sus familias la única consecuencia destacada, la responsabilidad asumida en solitario sobre sus hijos, cuando los había, y la propia condición de mujeres no dependientes, sin duda, modificaron su percepción de la realidad.

Para los reinos hispánicos peninsulares que inician el siglo XvI una de las grandes oleadas migratorias: la emigración a Ultramar, algunos trabajos pioneros propusieron una lectura complementaria y significativa sobre las posibilidades que se habían abierto a las mujeres solas -casadas con maridos ausentes, solteras o viudas-, en una ciudad como la Sevilla de la Carrera de Indias 7 . M. E. Perry definía la Sevilla

7. Recientemente, se ha intentado despejar la magnitud relativa de la jefatura de hogar femenina en la Sevilla del XVI con el recurso a fuentes complementarias de los vecindarios

(C) Ediciones Universidad de Salamanca / ®@ Stud. his., H. ${ }^{a}$ mod., 38, n. 2 (2016), pp. 237-285 
MARÍA JOSÉ DE LA PASCUA SÁNCHEZ

«A LA SOMBRA» DE HOMBRES AUSENTES:

MUJERES MALCASADAS EN EL MUNDO HISPÁNICO DEL SETECIENTOS

de entonces, recordando las palabras de Andrea Navagero, embajador veneciano en la corte de Carlos V de visita por la urbe en 1525, como una ciudad «en poder de las mujeres»; mujeres solteras y viudas, mujeres no dependientes, pero también casadas con marido ausente que hacían frente a la ausencia de los hombres de su familia, muchos emigrantes en Indias y aprovechaban los intersticios abiertos circunstancialmente en un sistema de género excluyente. Su presencia creciente en el mundo del trabajo, su mayor visibilidad en el espacio público, no se proyectó, proporcionalmente en lo simbólico, pues, según Perry, hubo un interés creciente por parte de las autoridades, en especial en la segunda mitad del siglo xvI, por silenciar este proceso. Ello no quiere decir, no obstante, que las experiencias de estas mujeres fueran inútiles en orden a afirmar su autonomía y extender su influencia ${ }^{8}$.

La realidad de la ausencia del cabeza de familia asociada a zonas de fuerte emigración masculina en los siglos XVII y xviII, que se establece también para Galicia, Vizcaya y otras zonas de la cornisa cantábrica, para Las Islas Canarias o en otros lugares en los que la ausencia frecuente del mismo era una condición básica de la economía de la zona en estos siglos -la Maragatería, por ejemplo, donde con una explotación agraria que convivía con la dedicación al transporte de los hombres de la familia ${ }^{9}$ o la costa de Huelva donde la actividad pesquera exigía estas ausencias más o menos temporales del cabeza de familia ${ }^{10}$ - nos pone en relación directa con el mayor número de mujeres casadas ejerciendo como cabezas de familia. De momento y en general no se puede precisar su proporción relativa respecto a los hogares con jefatura femenina, aunque sí tenemos indicios de una existencia significativa. Así, para el siglo XviII peninsular, que cuenta con un buen número

como los contratos de arrendamiento o diferentes memorias parroquiales, confirmándose un porcentaje de mujeres jefas de hogar cercano al 30 por ciento, por tanto, similar al que se obtiene para otras ciudades peninsulares como Ávila, Salamanca, Valladolid, Segovia en el censo de 1561. Como en aquellas, el subgrupo más numeroso estaba formado por viudas que, junto a solteras y casadas abandonadas por sus maridos, se repartían por todos los barrios de la ciudad, mostrando como colectivo una tendencia al crecimiento que sustentaba la sensación de sobreabundancia de mujeres solas, CARMONA, J. I.: Mercado inmobiliario, población, realidad social. Sevilla en los tiempos de la Edad Moderna. Sevilla, 2015, pp. 55-57 y 138-143.

8. Perry, M. E.: Ni espada rota ni mujer que trota: mujer y desorden social en la Sevilla del Siglo de Oro. Barcelona, 1993, pp. 23-41.

9. Rubio, L.: «Estructuras agrarias y modelos organizativos de las comunidades campesinas leonesas durante la Edad Moderna», Melánges de la Casa de Velázquez, XXIX:2, 1993, pp. 253-274.

10. Para la Tierra Llana de Huelva se destaca como fórmula reiterada de abandono de los deberes conyugales un proceso paulatino, iniciado con breves ausencias hasta llegar a la separación total y la ausencia del cónyuge relacionada con actividades económicas, RUiz, M.: Matrimonio, moral sexual y justicia eclesiástica en Andalucía occidental: la Tierra Llana de Huelva (1700-1750). Sevilla, 2011, pp. 180-188.

(C) Ediciones Universidad de Salamanca / ®@ Stud. his., H. ${ }^{a}$ mod., 38, n. 2 (2016), pp. 237-285 
MARÍA JOSÉ DE LA PASCUA SÁNCHEZ

«A LA SOMBRA» DE HOMBRES AUSENTES:

MUJERES MALCASADAS EN EL MUNDO HISPÁNICO DEL SETECIENTOS

de investigaciones que han aprovechado la abundancia de censos de la centuria y, particularmente, la información del Catastro de la Ensenada, los porcentajes de hogares con jefatura femenina se mueven entre el 10 y el 30 por ciento del total de hogares, aproximándose a la primera cifra ciudades como Burgos ${ }^{11} \mathrm{o} \mathrm{Cádiz}^{12}$, y a la segunda poblaciones como Granada $^{13}$ o algunas gallegas ${ }^{14}$. En la Montaña de León estos oscilan entre el 20 y el $17 \%$ en la segunda mitad del XviII ${ }^{15}$ y en la comarca montañosa del sur de La Mancha, la Sierra de Alcaraz, el porcentaje obtenido es el 15,8 ${ }^{16}$. Al frente de estos hogares, suele estar una viuda, ya se trate de Burgos, Granada, Castilla-La Mancha ${ }^{17}$, León, o diferentes localidades gallegas y solo en una pequeña proporción de los mismos la «jefa» es una mujer casada $-3,8 \%$ en Burgos a mediados del XviII ${ }^{18}, 0,9 \%$ en Santiago de Compostela en 1708 y en $1752^{19}$, o 0,8\% en la Sierra de Alcaraz a mediados del XviII ${ }^{20}$. Las cifras, en general más débiles, de mujeres casadas al frente de un hogar explican una menor atención a estos hogares, en relación, por ejemplo, con los dirigidos por viudas. Hay que tener en cuenta, sin embargo, que su distribución no es homogénea ni en el territorio europeo ni en el peninsular y que constituyen tanto una realidad sistémica relacionada con el modo de reproducción social como dinámica, directamente relacionada con variables demográficas y sociales. En algunas zonas

11. SANZ, F. F.: «Familia, hogar y vivienda en Burgos a mediados del siglo XVIII. Entre cuatro paredes, compartiendo armarios, camas, mesas y manteles», Investigaciones históricas, 22, 2002, pp. 165-211.

12. Pascua, M. ${ }^{a}$ J. de la: «Social Reproduction and Alone Women Households: Cadiz in the 18th Century», Women, Family, Private Life and Sexuality. 4th Conference of the International Federation for Research in Women's History. Belfast, Queen's University, 2003.

13. El número de mujeres responsable de su familia se eleva al 26,78\%, Birriel, M. M.a: «Jefaturas de hogar femeninas en la ciudad de Granada (1752), I: Caracterización demográfica del hogar», en Cortés, A. L., López-Guadalupe, M. L., SÁnchez-Montes, F. (Eds.): Estudios en Homenaje al profesor José Szmolka Clares. Granada, 2005, pp. 591-604.

14. La zona rural ofrece, en Galicia, porcentajes de hogares dirigidos por mujeres similares, algo inferiores al mundo urbano, RIAL, S.: «Las mujeres solas en la sociedad semi-urbana gallega del siglo XVIII», Obradoiro de Historia Moderna, 8, 1999, 169-197, p. 179.

15. PÉrez, M. ${ }^{a}$ J.: La familia, la casa y el convento. Las mujeres leonesas durante la edad Moderna. León, 2012, pp. 49-50.

16. García, F.: «Mujer, hogar y economía familiar. Desigualdad y adaptación en la Sierra de Alcaraz a mediados del siglo XVIII, Hispania, LVII (1), 195, 1997, 115-145, p. 119.

17. Se enfatiza este dato para la Castilla rural meridional en GARCíA, F.: «Investigar la soledad. Mujeres solas, casa y trayectorias sociales en la Castilla rural a finales del Antiguo Régimen», Obradoiro de Historia Moderna, 24, 2015, pp. 141-169.

18. SANZ, F. J.: «Familia, hogar y vivienda», op. cit., p. 170.

19. Rial, S. M.: Las mujeres en la economia urbana del Antiguo Régimen: Santiago durante el siglo XVIII. Santiago de Compostela, Edicios do Castro, 1995, p. 30.

20. García, F.: «Mujer, hogar y economía familiar», op. cit., p. 120.

(C) Ediciones Universidad de Salamanca / ®@ Stud. his., H. ${ }^{a}$ mod., 38, n. 2 (2016), pp. 237-285 
MARÍA JOSÉ DE LA PASCUA SÁNCHEZ

«A LA SOMBRA» DE HOMBRES AUSENTES:

MUJERES MALCASADAS EN EL MUNDO HISPÁNICO DEL SETECIENTOS

de los territorios hispanos, donde se ha valorado el impacto demográfico de la emigración, los resultados son concluyentes. Entre la población canaria del siglo XVIII, por ejemplo, una emigración de carácter predominantemente masculino va a tener un impacto demográfico y social destacado, señalándose el alto índice de hijos ilegítimos, el aumento de los adulterios, relaciones extramatrimoniales y prácticas abortivas por parte de mujeres abandonadas por hombres casados ausentes en Indias ${ }^{21}$. También en Galicia hacia 1752, con un 20\% de hogares regentados por mujeres «viviendo sobre sí», especialmente en la Galicia Occidental, se hace significativa la proporción de mujeres casadas al frente de su familia en zonas de fuerte emigración masculina como Ares ${ }^{22}$. Más complejidad aún que precisar la proporción de las llamadas «viudas blancas» ${ }^{23}$ tiene identificar dentro del grupo de mujeres jefas del hogar a las malcasadas. Su marginación era mayor, por lo que su rastreo en las fuentes queda dificultado, además, por la voluntad de silencio de muchas de estas mujeres y la discreción que envuelve en la época las cuestiones relacionadas con la honra. Para seguir su rastro se suele acudir a los registros de hospitales y de casas de acogidas y de otras instituciones asistenciales, donde las mujeres quedan asociadas a situaciones de marginalidad y, con frecuencia, al afán correctivo y de mantenimiento de los valores socioculturales dominantes de los grupos dirigentes. Allí aparecen, en la Murcia del siglo XviıI ${ }^{24}$, en Cuenca entre el último cuarto del siglo $\mathrm{XVIII}^{25}$, en la Barcelona del siglo $\mathrm{XVIII}^{26}$, en

21. Hernández, M.: «La emigración americana y su influencia sobre la vida conyugal en Canarias durante el siglo XviII", Anuario de Estudios Atlánticos, 36, 1990, pp. 353-377, MARTín, J. F., DíAz, M. ${ }^{a}$ C.: «La natalidad ilegítima en la formación social canaria: las repercusiones de la emigración americana», V Coloquio de Historia Canario-Americana, t. I., 1985, pp. 205-218.

22. ReY, O.: «Les femmes seules du Nord-Ouest de l'Espagne : trajectoires féminines dans un territoire d'émigration, 1700-1860 », Annales de Démographie Historique, 2006, pp. 13-30 y Rial, S. M.: «Las mujeres solas en la sociedad», op. cit, p. 179.

23. Palazzi, M.: «Female Solitude and Patrilineage: Unmarried Women and Widows during the Eighteenth and Nineteenth Centuries", Journal of Family History, 4, 15, 443-459, p. 444.

24. Hourcade, J. M.: «Asistidas, recogidas, corregidas: el lugar de la mujer en el sistema asistencial del siglo XVIII», en Congreso Internacional de Historia de la Familia: Nuevas perspectivas sobre la sociedad europea, 1994. Murcia, 1997, pp. 233-240.

25. Fernández, A.: «La Casa de recogidas de Cuenca (1776-1845): desobediencia, delitos y penas de las mujeres entre la Ilustración y el Romanticismo», en PAscuA, M.a J. de la, EsPigado, G. (Eds.): Frasquita Larrea y Aherán. Europeas y españolas entre la Ilustración y el Romanticismo, 1750-1850. Cádiz, Universidad, 2003, 297-323.

26. Carbonell, M.: «Les dones pobres a la Barcelona del segle XviII», Historia social, 8, 1990, 123-135 y «Fuentes para la Historia de las Mujeres en los archivos asistenciales, siglos XVI-XVIII)», en BIRRIEL, M. (Ed.): Nuevas preguntas, nuevas miradas. Fuentes y documentación para la bistoria de las mujeres (siglos XVI-XVIII). Granada, 1992, pp. 59-78.

(C) Ediciones Universidad de Salamanca / ®®@ Stud. his., H. ${ }^{a}$ mod., 38, n. 2 (2016), pp. 237-285 
MARÍA JOSÉ DE LA PASCUA SÁNCHEZ

«A LA SOMBRA» DE HOMBRES AUSENTES:

MUJERES MALCASADAS EN EL MUNDO HISPÁNICO DEL SETECIENTOS

Granada ${ }^{27}$ o en diferentes poblaciones de la actual provincia de Cádiz como El Puerto de Santa María ${ }^{28}$, Jerez de la frontera ${ }^{29}$, o la capital ${ }^{30}$ entre otros. En estas fuentes de carácter asistencial subyace, no obstante, el discurso que fundamenta la acción asistencial apoyada sobre los principios rectores de una sociedad que es patriarcal y asocia el éxito o el fracaso de las mujeres a su situación respecto al matrimonio. En el caso de las malcasadas, obviamente, mala. Aunque es imposible sustraerse de ese código de valores, sí es importante acudir a otras fuentes que permitan perspectivas más amplias sobre la situación de un colectivo, siempre bajo la sombra de un hombre, y las posibilidades de mujeres casadas y mal casadas para llevar una existencia con ciertos niveles de autonomía.

La migración estacional-temporal del cabeza de familia o de algunos de sus miembros era, con frecuencia y en las economías preindustriales una constante relacionada con la explotación de fuentes de beneficio complementarias de aquellas de las que dependía la subsistencia de la familia. Ello implicaba movimientos de población más o menos temporales, relacionados con la actividad económica. La antigua y larga tradición de los movimientos migratorios desde el norte de España hacia las grandes ciudades castellanas, Madrid o los centros mercantiles de Andalucía

27. Arias de SaAvedra, I. y López-Guadalupe, M. L.: "Asistencia sanitaria femenina a finales del Antiguo Régimen: el caso del Hospital de la Caridad y Refugio de Granada», Cuadernos de Historia Moderna, XIV, 2015, pp. 33-61.

28. Pascua, M. J. de la: «Pobreza y asistencia social en el Jerez del siglo XviI», en $I V$ Jornadas de Historia de Jerez. Jerez, Biblioteca de Urbanismo y Cultura, 1992, pp. 33-44.

29. El análisis de un Listado de Pobres que se realiza en Jerez en 1751 para la distribución de ropa en las parroquias jerezanas constituye una ventana a la pobreza femenina e infantil en la ciudad de Jerez de la Frontera a mediados del xviII, proporcionando la lista nominal de 120 mujeres (viudas - un tercio de la muestra-, huérfanas -algo menos de un quinto del total-, pobres, ciegas, inválidas, ancianas o muy desnudas y de 462 niños y niñas pobres que vivían en la parroquia de Santiago), PASCUA, M. ${ }^{\mathrm{a} J}$. de la: «Madres, mujeres y solas: el oficio de vivir en la España del siglo XVIII», en FrANCO, G. (Ed.): Debates sobre la maternidad desde una perspectiva bistórica (Siglos XVI-XX). Barcelona, Icaria, 2010, pp. 231-270.

30. La Fundación de la Hospitalidad doméstica fue instituida por el obispo gaditano Antonio Martínez de la Plaza en 1793, con el objetivo de dotar a las parroquias de Cádiz de fondos destinados a la ayuda a domicilio de familias necesitadas, entre ellas las de mujeres con maridos ausentes. Aunque contamos para el periodo 1793-1810 con el detalle de la cuantía de las limosnas recibidas y en qué tipo de ayuda se empleó -enfermos, farmacia, socorros a familias y gastos de la institución-, el recuento justificativo no desglosa la condición ni las circunstancias de las familias necesitadas. EcheA, J. de: La hospitalidad doméstica. Cádiz, Nicolás Gómez de Requena, Impresor del Gobierno, 1811 (Biblioteca de Temas Gaditanos, C. 95, F. 14). Hubo, por otra parte, fundaciones de instituciones específicas de acogida de mujeres solas, PASCUA, M. ${ }^{a}$ J. de la: «La fundación de la Casa de las Viudas: el gesto ilustrado de un comerciante de Damasco», en La burguesía de negocios en la Andalucía de la Ilustración. Cádiz, Diputación Provincial, 1991, pp. 283-297.

(C) Ediciones Universidad de Salamanca / ®@ Stud. his., H. ${ }^{a}$ mod., 38, n. 2 (2016), pp. 237-285 
está suficientemente documentada y analizada ${ }^{31}$. Aunque con distintos ritmos temporales, estos desplazamientos por motivo laboral, estacionales o temporales, de campesinos, artesanos, carreteros, marineros y trabajadores en general se reactivan desde el último cuarto del siglo xvir y se mantienen muy activos a lo largo de todo el XviII ${ }^{32}$. Por otra parte, el establecimiento allende el Atlántico de una nueva frontera en la que la ilusión de mejorar de vida y conseguir fortuna parecían realizables, provocó la migración de hombres solteros, viudos y casados a Ultramar y un buen número de separaciones de esposos y familias, más o menos definitivas. La Corona intentó controlar, desde el primer momento, la emigración de hombres casados o prometidos con leyes que exigían una licencia de sus mujeres a aquellos que intentaban embarcar y, en el caso de que esta no se hubiera dado, con otras leyes que preveían la extradición y el regreso forzoso al hogar de todos los que permanecían en las Indias sin la misma ${ }^{33}$. El abandono de las obligaciones familiares del cabeza de familia constituye el fundamento de una serie de ordenanzas y leyes, recogidas en la Recopilación de las Leyes de Indias (1634), que tenían el objetivo de regular el tema de la emigración de hombres casados y desposados a América, y que se pone en marcha desde el comienzo de la colonización para hacer frente a una realidad en ascenso. Obviamente, el objetivo concreto de las mismas era procurar, para los territorios hispanos de Ultramar, un clima social de moral y orden sustentado en el modelo de familia dominante -la establecida a partir del sacramento del matrimonio entre una pareja heterosexual, en una unión indisoluble bajo la autoridad del cabeza de familia y destinada a criar hijos para el Cielo-, pero el dispositivo legal que a partir de unas primeras medidas parciales en La Española $(1505,1509,1530)$ y Nueva España $(1533)$, se extenderá al conjunto de los territorios bajo poder español en 1544, pondrá en manos de las mujeres de ausentes un amplio y detallado procedimiento encaminado a procurar el regreso

31. CAmps, E.: «Las migraciones locales en España, siglos XVI-XIX», Boletín de la ADEH, XI, 1, 1993, pp. 26-30, SALAS, J. A.: «Movimientos migratorios en la España de la Edad Moderna», Boletín de la ADEH, VI, 2, 1988, pp. 33-37.

32. LANZA, R.: «De norte a sur: las migraciones de la fachada cantábrica en la España Moderna», en EIRAS, A., GonZÁlez, D. (Coords.): Movilidad interna y migraciones intraeuropeas en la Península Ibérica. Actas del Coloquio Europeo sobre Migraciones. Santiago de Compostela, 2002, pp. 17-53, entre otros.

33. Pascua, M. ${ }^{a}$ J. de la: «La cara oculta del sueño indiano: mujeres abandonadas en el Cádiz de la Carrera de Indias», Chrónica Nova, 21, 1993-1994, pp. 441-468; Mujeres Solas: historias de amor y de abandono en el mundo hispánico. Málaga, CEDMA, 1998; «Estrategias para el regreso sobre un mar de olvidos: Las mujeres de los ausentes en Indias ante los tribunales (1695-1804)», I Coloquio Científico ANDATLAN. Andalucía en el mundo atlántico moderno: agentes y escenarios. Sevilla, octubre, 2015, en prensa.

(C) Ediciones Universidad de Salamanca / ®®@ Stud. his., H. ${ }^{a}$ mod., 38, n. 2 (2016), pp. 237-285 
MARÍA JOSÉ DE LA PASCUA SÁNCHEZ

«A LA SOMBRA» DE HOMBRES AUSENTES:

MUJERES MALCASADAS EN EL MUNDO HISPÁNICO DEL SETECIENTOS

forzoso de sus maridos ${ }^{34}$. Una larga serie de leyes $(1544,1550,1565,1569,1578$, $1579,1607,1610,1614,1619,1626,1751$ y 1774) muestran, en la insistencia de la promulgación tanto como en su tenor, la importancia del desplazamiento constante de hombres casados a la América Española. En este contexto, Cádiz se dibuja como una de las poblaciones peninsulares donde la presencia de mujeres casadas con maridos ausentes se hace visible como un problema social ${ }^{35}$. La Ciudad, Cabecera de las flotas a Indias desde 1680, recibe un significativo aporte de población foránea, peninsular y extranjera, aunque es a la vez plataforma de la emigración a Indias. Su población, junto a características demográficas como bajas tasas de nupcialidad, fecundidad y de natalidad, acceso tardío al matrimonio y elevada proporción de celibato definitivo ${ }^{36}$, destaca por un notable número de hogares encabezados por mujeres casadas y por tanto como buen observatorio para estudiar los hogares con jefatura femenina. De hecho, las cifras corroboran la impresión obtenida a partir de otras fuentes y es la única ciudad analizada del xviII peninsular en la que los hogares presididos por mujeres casadas se aproximan significativamente a los de viudas. Para cuantificar este fenómeno analicé un padrón de levas que se realizó en Cádiz en $1773^{37}$, cuyo estudio arrojó como conclusiones destacadas la presencia de una mayoría de mujeres solas viudas $-53,91 \%-$, una proporción más baja de solteras $-11,66 \%-y$, como nota destacable, una notable cantidad de mujeres casadas como jefas de esos hogares -el 34,43\%-, de las que más de un tercio tenía a sus maridos ausentes en Indias. Más allá de esta cuantificación que permitió establecer un orden de magnitud del fenómeno, otros datos y la casuística que sobre el fenómeno ofrecen diferentes fuentes (requisitorias, testamentos, cartas), permiten la profundización en diversos aspectos del problema.

La localización en el Obispado de Cádiz de una amplia serie de «Requisitorias a Indias» me permitió en su momento el acceso a las circunstancias económicas, familiares y vitales de alrededor de trescientas mujeres abandonadas por sus

34. Pascua, M. ${ }^{a}$ J. de la: «Estrategias para el regreso sobre un mar de olvidos», op. cit.

35. «Seis, ocho o más años, a dos o tres mil leguas de sus casas y muchas veces no envían nunca ni un solo real para ayudar a sus familias [...] Porque qué es lo que podemos ver con nuestros propios ojos en las calles, si no es a pobres mujeres abandonadas buscando comida como mendigos, o con otras menos lícitas maneras», Cienfuegos, B.: La Pensadora gaditana. Cádiz, Imprenta M. Ximénez, 1786, I, pp. 248-258 (Biblioteca de Temas Gaditanos, C/95, $\mathrm{F} / 14$ ).

36. Pérez, J.: Cádiz, la ciudad desnuda. Cambio económico y modelo demográfico en la formación de la Andalucía contemporánea. Cádiz, 1992.

37. Pascua, M. J. de la: «Social Reproduction and Alone Women Households», op. cit., «Madres, mujeres y solas», op. cit. y «Vivir en soledad, vivir en compañía: las mujeres y el mundo familiar en el siglo XviII hispánico», en GARCíA, M. R. (Ed.): El siglo XVIII en femenino. Madrid, Síntesis, 2016, pp. 147-186.

(C) Ediciones Universidad de Salamanca / ®@ Stud. his., H. ${ }^{a}$ mod., 38, n. 2 (2016), pp. 237-285 
MARÍA JOSÉ DE LA PASCUA SÁNCHEZ

«A LA SOMBRA» DE HOMBRES AUSENTES:

MUJERES MALCASADAS EN EL MUNDO HISPÁNICO DEL SETECIENTOS

esposos que interponían ante la justicia eclesiástica del Obispado de Cádiz, con la alianza de leyes seculares mencionadas, la petición de una repatriación de sus maridos, ausentes mayoritariamente en Indias ${ }^{38}$. La serie que se desgranaba entre los años 1695 y 1804, presenta como momentos álgidos los lustros que van de 1750 a 1779 , periodo que concentra 183 de las 336 requisitorias, situándose el número de requisitorias por cada cinco años en torno a la treintena y destacando 17651769 con 38 requisitorias tramitadas desde el obispado de Cádiz. La mayoría de las solicitantes procedían de Cádiz y ciudades de su actual provincia y del resto de Andalucía (fundamentalmente de Sevilla y Huelva), pero también destacaba un pequeño grupo de 33 mujeres con origen en distintas tierras de España y en el extranjero ${ }^{39}$. Los requeridos, solo en una tercera parte eran naturales de Cádiz o de las tierras andaluzas, el otro tercio del resto de España y la tercera parte restante se repartía entre los nacidos en el extranjero, destacando los genoveses y los franceses ${ }^{40}$. De todos los requeridos, 280 estaban en la América Española, una tercera parte en el Virreinato de Nueva España ${ }^{41}$. Al margen de estas características básicas de la muestra de mujeres y hombres implicados, las situaciones que tanto los escritos de demanda como las pruebas testimoniales que estas mujeres presentaban al juez provisor, reflejaban una vida de dificultades económicas y de carencias de todo tipo, también afectivas, para ellas y los hijos que habían quedado a su cargo ${ }^{42}$. Pero la mayoría de las explicaciones que las susodichas ofrecían, explicaciones sencillas y directas, sobre sus respectivas circunstancias, enmarcadas en la lógica que presidía las identidades femeninas heterodesignadas, dejaban a la deducción obvia de los jueces situaciones graves de riesgo de exclusión social para toda la familia. Mujeres paulatinamente empobrecidas o pobres de solemnidad, a cargo de una familia que con frecuencia necesitaba ayuda para subsistir ${ }^{43}$ y maridos ausentes durante largos periodos de tiempo ${ }^{44}$ sin enviar noticias, socorros, ni siquiera unas palabras de consuelo ${ }^{45}$;

38. Pascua, M. ${ }^{a}$ J. de la: Mujeres Solas, op. cit.

39. Idem, p. 346.

40. Idem, p. 347.

41. Idem, pp. 349-350.

42. Hay noticia expresa de 193 hijos legítimos que convivían con 101 de estas mujeres solas, Idem, p. 351.

43. De 177 mujeres, el $65 \%$ se define como pobre, el $23 \%$ como «pobre de solemnidad» y el 6,5\% como pobre mendicante; un pequeño grupo está a expensas de familiares o amigos, Idem, pp. 226-227.

44. Los valores modales de la duración de la ausencia del marido se hallan entre los 3 y los 14 años, Idem, p. 217 y p. 352. 353.

45. Solo 5 solicitantes declaran recibir ayuda y 48 que la recibieron al principio, Idem, p.

(C) Ediciones Universidad de Salamanca / @@ Stud. his., H. ${ }^{a}$ mod., 38, n. 2 (2016), pp. 237-285 
maridos que mantenían con frecuencia al otro lado del océano además de un buen pasar-acusación frecuente en los expedientes-, otras relaciones afectivas y otras familias. La expresión, en general contenida, de estas mujeres sobre sus emociones, muy probablemente encontradas y variables durante la larga ausencia, se intuyen a través de los breves retazos que apuntalan la descripción de sus circunstancias. Así, cuando declaran ante el juez la ausencia de cartas a lo largo de 20 años en las que el susodicho "ni se ha dignado a responderme» ${ }^{46}$, ha devuelto las suyas bajo el argumento "que no le escribiese más» ${ }^{47}$ o da como única respuesta el silencio más absoluto. Un silencio que puede ejemplificarse en casos como el de María de Utrera $^{48}$, Juana Piñera ${ }^{49}$, Agustina Pérez de Sandoval ${ }^{50}$ y muchos otros, siendo esta quizá la actitud más frecuente de estos hombres ausentes, al menos tal y como se desprende del reproche de estas mujeres.

Independientemente de la queja por el silencio y el olvido, las casadas con maridos ausentes tenían que vivir y mantener a sus familias. La fuente, por su propia naturaleza, no es un medio adecuado para conocer cómo sobrevivían. En la necesidad de ser concisas y directas en su demanda ante el juez, el propio sentido común dictaba la conclusión sobre una situación económica mala para una mujer supuestamente dependiente de un marido ausente. Por otra parte, en un buen número de ocasiones la realidad socioeconómica de la propia familia antes de la marcha del marido no era buena, algo que se puede deducir del argumento explícito que forma parte de las razones de la emigración del cabeza de familia: habían ido a buscarse la vida. En esta lógica, solo un pequeño grupo de 28 mujeres ofrecía detalles sobre el tipo de trabajo en el que se empleaba -reducidos prácticamente a los de servicio doméstico, lavandera, costurera y ama de cría- ${ }^{51}$, en línea con el perfil que obtenemos de otras fuentes para las mujeres cabezas de familia de los

46. Requisitoria de la granadina Sebastiana Sáenz, esposa de un alférez del regimiento Saboya, ausente desde hacía 20 años, Idem, p. 244.

47. Petición del esposo de Ana Carreño, quien además le había devuelto las cartas, Idem, p. 245.

48. Su marido, establecido en Buenos Aires como maestro sangrador, en nueve años no había dado señales de vida, aun constándole su «extrema necesidad», Idem, p. 244.

49. Cuenta que su esposo, que marchó a Indias como capitán de dragones de caballería en el regimiento Almansa, permanecía en Puerto Príncipe sin haberla escrito. En este tiempo su hija había fallecido, Idem, p. 244.

50. La demandante, natural de Badajoz, tenía a su marido ausente en Cartagena de Indias desde hacía cuatro años, periodo en el que no había recibido ni noticias ni socorros «porque a mis cartas no responde y aunque a las personas que le preguntan contesta que volverá no lo cumple», Idem. p. 244.

51. Idem, p. 355 .

(C) Ediciones Universidad de Salamanca / ®@ Stud. his., H. ${ }^{a}$ mod., 38, n. 2 (2016), pp. 237-285 
MARÍA JOSÉ DE LA PASCUA SÁNCHEZ

«A LA SOMBRA» DE HOMBRES AUSENTES:

MUJERES MALCASADAS EN EL MUNDO HISPÁNICO DEL SETECIENTOS

barrios más pobres del Cádiz del xviII ${ }^{52}$. Según se puede concluir del análisis del padrón de 1773, donde la visibilidad de la ocupación laboral de las mujeres cabezas de familia es mucho mayor, especialmente en los populares barrios de Merced y San Roque, en los que se registra la actividad laboral o la actividad económica del 90 por ciento de las ellas. En la mayoría de los casos son actividades relacionadas con los servicios, entre las que destaca el oficio de lavandera y los de costurera y bordadora. También en esta zona de forma exclusiva aparecen censadas como mujeres solas pordioseras y mujeres que viven de la limosna $-3,60 \%$ - y 31 prostitutas $-5,88 \%-$. Hay, sin embargo, una actividad «laboral» presente en toda la ciudad: la de casera, que afecta al $11,6 \%$ de las mujeres cabezas de familia que declaran actividades económicas. A pesar de que es una actividad que las mujeres de los barrios populares también realizan, en ellos es una ocupación con presencia mucho más débil. Con toda probabilidad la condición de casera designa actividades distintas. De un lado, la tarea de organización de la vida común de las fincas donde habitaban estas mujeres junto a otros vecinos, en diferentes pisos o cuartos de la misma y en régimen de alquiler. La casera ordenaba los turnos de limpieza en zonas comunes como..., como escaleras, patios y portales, y en los casos en los que se compartieran, cocinas, excusados o lavaderos, ejerciendo un control de las costumbres relacionadas con la seguridad y el decoro -cierre y apertura de la puerta exterior con la llegada de la noche o al empezar el día, vigilancia sobre el cumplimiento de ciertas normas de convivencia que constituían motivo de riñas entre los vecinos-, funciones que podían extenderse al cobro de los pagos del alquiler o a la vigilancia sobre posibles casos de subarriendo. La actividad, en general, no tenía comúnmente más recompensa salarial que el disfrute de una vivienda sin el pago del correspondiente alquiler pero conllevaba, para quien la ejercía, no solo una ayuda a su mantenimiento, sino también cierta aureola de poder en la comunidad vecinal. Sin embargo, bajo el concepto de casera se refugia también una dedicación muy diferente que ejercían ciertas mujeres propietarias de casas y que daban cobijo en las mismas a huéspedes como medio de procurarse un medio de vida. Esta, sin duda, fue una actividad de relativa importancia en Cádiz, donde a una densidad de población altísima ${ }^{53}$, se unía una abundante población transeúnte y el concurso de una población inmigrante que buscaba en la ciudad su particular El Dorado y que mantenía alta la demanda de pisos y habitaciones de alquiler ${ }^{54}$.

Más escasa representación tiene entre las mujeres solas censadas en el padrón gaditano de 1773 otros oficios tradicionalmente femeninos como el de comadrona

52. Pascua, M. ${ }^{a}$ J. de la: «Madres, mujeres y solas», op. cit., pp. 231-270.

53. 680 habt. por ha en 1787, Pérez, J.: Cádiz, La ciudad desnuda, op. cit., pp. 143-165.

54. Pascua, M. J. de la: «Vivir en soledad, vivir en compañía», op. cit., pp. 147-186.

(C) Ediciones Universidad de Salamanca / ®@ Stud. his., H. ${ }^{a}$ mod., 38, n. 2 (2016), pp. 237-285 
y maestra de niñas, sobre todo si los comparamos con los relacionados con los servicios. Entre estos últimos destacan también los de confección de ropa y accesorios del vestir -bordadora, calcetera, cotillera, sombrerera, botonera, cordonera, ojaladora-; los de producción y distribución de alimentos -confitera, panadera, caracolera, mondonguera (estos dos últimos ejercidos siempre por gitanas), freidora de pescado, de tortillas, buñuelera, garbancera- que se unen a un significativo número de mujeres que venden en puestos del mercado o están al frente de una bodega, una posada, una taberna, un café o un billar. También son importantes en número y están repartidas por toda la ciudad las mujeres que poseen tiendas de ropa hecha (7), de modas (3), de seda (9), de listonería (2), mercerías (2), de zapatos (1), de calderería (1), de jabones (1), de comestibles (1) o de tabacos (2) -en total 29 mujeres-. La fabricación de almidón, de fideos, de pan, de velas o tabacos está asimismo representada y no faltan oficios como el de cómica, mandadera, beata o gallinera desempeñados por una o dos mujeres.

La diversidad de actividades de las empadronadas en los barrios más populares, contrasta con la relativa monotonía de los trabajos realizados por las mujeres cabezas de familia del resto del recinto urbano, reducidos, en la práctica, al hospedaje y a la propiedad de tiendas de diverso tipo. Tampoco es raro que estas mujeres compatibilicen dos o más actividades. La del ejercicio de casera con la costura se registra con cierta frecuencia en el barrio de la Merced (en casadas con marido ausente, como son los casos de María Bretón o Antonia Bejarano), lo mismo que el de lavandera-casera (Catalina Aparicio, casada con marido ausente). El «pordioseo» es otra actividad bastante representada en este popular barrio, lo mismo que la prostitución (tres mujeres que viven solas en una accesoria de la calle Yedra, cuatro mujeres «mundanas» de la calle Jesús, o las 9 mujeres que, en la calle Sta. Elena, comparten la accesoria del número 203). Sobre otras formas de sobrevivir, como estar a expensas del marido o de otros familiares -14\%-, entre ellos los hijos -9,5\%-, la información del padrón no es homogénea y está ausente en muchos barrios. No falta tampoco un pequeño grupo de mujeres cabezas de familia con una posición económica deshogada que se mantiene viviendo de sus rentas o en el ejercicio de una actividad económica de cierto prestigio. Viudas como Sara Purcell o Catalina Porter y Wadding, titulares de Casas Comerciales, viven en el barrio de San Carlos, junto a varios hombres mayores de edad, entre hijos y empleados de la Casa. En la zona comercial por excelencia del Cádiz del Setecientos, la situada alrededor de la calle Nueva, donde se hallaban las mejores tiendas, se localizan un buen número de titularidad femenina. Las viudas Catalina Castañeda, genovesa, María Brea y Beatriz Piedrabuena, tenían tiendas de listonería y ropa de confección, al igual que María Vidal y María Núñez, casadas con marido ausente. Próximas a estas tiendas, apenas un par de pasos, aunque con

(C) Ediciones Universidad de Salamanca / ®@ Stud. his., H. ${ }^{a}$ mod., 38, n. 2 (2016), pp. 237-285 
una localización menos distinguida y más popular, Luisa de Vargas tenía tienda de listonería, y Francisca Malón y María Carrasco, sendas tiendas de seda. En el mismo barrio, la viuda María Álvarez regentaba su tienda de modas. En otra zona noble, la calle Ancha, había otras tantas tiendas de modas propiedad de mujeres cabezas de familia: la de la gaditana María Oláiz, de 26 años, la de la francesa Mariana Rider, de 36 y la de la parisina María Reno, de 21 años ${ }^{55}$.

Las historiadoras vienen insistiendo en la necesidad de resituar el trabajo femenino más allá de la encrucijada de vida y de la supervivencia, en una perspectiva social y política. Desde la descripción de prácticas laborales marginales y la reflexión teórica necesaria para valorar esas mismas prácticas, se ha pasado en los estudios actuales a enfatizar la imbricación existente entre familia y trabajo en la experiencia de las mujeres y también la relación entre pobreza y actividad laboral. Estos dos últimos aspectos conocieron un gran desarrollo en los años noventa e interesan especialmente en relación con el tema que aquí planteamos. Junto a ellos, nuevos conceptos relacionados con la «economía del cuidado», los tiempos, o las «economías de improvisación» que enmarcan la actividad de las mujeres dentro del objetivo más amplio de la sostenibilidad de la vida, han puesto sobre la mesa la discusión sobre la complejidad de los itinerarios laborales de las mujeres a lo largo del curso de su vida ${ }^{56}$.

Otros registros documentales, como los protocolos notariales y los testamentos, en particular, permiten ampliar el recorrido de estas mujeres por el mercado del trabajo y sus posibilidades o condicionantes al tiempo de acceder a un trabajo cualificado y bien remunerado. A partir de ellos es posible trazar trayectorias laborales y estrategias de supervivencia más complejas de las que habitualmente se pronostica. Efectivamente, la mayoría de las declaraciones de las demandantes ante el obispado de Cádiz abundaban en los aspectos negativos de su ocupación laboral. La ausencia de su marido en Buenos Aires, había obligado a Juana Fernández, según declaraba, a buscarse la vida y en esos 19 años de ausencia a «sujetarme a cualesquiera trabajo que me ha salido» ${ }^{57}$. La cordobesa Josefa Ruiz, declaraba que mantenía a sus dos hijos con el oficio de lavandera. Los testigos que presentaba para justificación de su pobreza, algo que le permitirá tramitar todo el proceso sin gastos, confirmaban las dificultades que tenía para sacarlos adelante a pesar de su trabajo de lavar ropa ajena ${ }^{58}$. Pero tenemos un testimonio

55. Pascua, M. ${ }^{a}$ J. de la: «Vivir en soledad, vivir en compañía...», op. cit.

56. Carbonell, M.: «Trabajo femenino y economías familiares», en Morant, I. (Dir.): Historia de las mujeres en España y América Latina. Vol. II. Madrid, Cátedra, 2005, pp. 237-262.

57. Pascua, M. J. de la: Mujeres Solas, op. cit., p. 232.

58. Idem, p. 232. 
muy rotundo en el expediente de Juana Pérez, quien declaraba que ella y su hija dependían de su trabajo personal que «como de una mujer apenas alcanza para comer miserablemente y siempre desnudas ${ }^{59}$.

Las investigaciones pioneras sobre el mundo del trabajo femenino en la época preindustrial y en el contexto de los desequilibrios generados por el tránsito de las economías pre-industriales al mundo de la industrialización, y concretamente la de Alice Clark (Working Life of Women, 1919) ${ }^{60}$, ya habían sugerido algunas consideraciones importantes sobre el tema. Así, la necesidad de partir del lugar que las mujeres ocupaban en la organización económica de las respectivas sociedades -en este caso la sociedad inglesa en el siglo XVIII-, dando relevancia al trabajo en el hogar -un hogar que la historiografía tradicional venía considerando más como boudoir que como place work- y a la compatibilización de la actividad productiva fuera de casa con el trabajo en ella y las responsabilidades maternas. El análisis de Clark, que hacía un recorrido por las actividades de las mujeres en los distintos sectores y subsectores económicos (el capital, la agricultura, la fabricación textil, el comercio y diferentes profesiones), señalaba la importancia que, para la ocupación laboral de las mujeres, habían tenido los cambios en la economía inglesa, concretamente el tránsito por tres sistemas de la organización industrial-Domestic industry, Family Industry y Capitalism Industry-, y los efectos de la Revolución Industrial en la posición de las mujeres como trabajadoras ${ }^{61}$. La consecuencia primera de esta obra fue romper con la visión que se tenía de las mujeres y su actividad como una especie de «factor estático» en el desarrollo social y, por tanto, historizar su relación con el trabajo ${ }^{62}$. Otro efecto fue mostrar que en el sistema marco en el que se integró la producción femenina y su posición respecto al mercado del trabajo hasta siglo xvIII -el llamado Family Industry System, donde la familia era la unidad de producción, de cambio, de capital y de fuerza laboral- las mujeres mantuvieron una presencia muy amplia y diversificada ${ }^{63}$ y fundamental en algunos sectores como la manufactura de tejidos, aunque con la constante de empleos mal pagados ${ }^{64}$. Además de

59. Idem, p. 233.

60. Clark, A.: Working Life of Women in the Seventeenth Century. Londres, G. Routledge and Songs, 1919.

61. Idem, p. 7.

62. Idem, p. 4.

63. En la Inglaterra de los siglos XVII y XVIII, localizó la presencia de mujeres empleadas como agentes de navegación, viudas que contrataban con la Compañía de las Indias Orientales, propietarias de barcos, contratistas o asentistas del Ejército y la Marina, mujeres prestamistas que aparecían en las listas como acreedores de comerciantes, o entre los mayores propietarios de carbón, Idem, pp. 30-34.

64. Idem, pp. 9-15. 
historizar y dar relevancia a la relación de las mujeres con el mercado de trabajo, Clark señalaba otras direcciones de análisis necesarias, una de ellas era, sin dejar de buscar respuestas generales, incorporar el análisis de las vidas individuales ${ }^{65}$, no solo de las mujeres de las clases altas o aquellas que tuvieron un papel relevante en los negocios, sino también de todas aquellas otras de las clases populares, incluso, de las clases con dificultades de supervivencia, a fin de comprender las formas en que se había encauzado la energía productiva de estos grupos.

Investigaciones como las de Peter Kriedte, Hans Medick y Jürgen Schlumbohm $(1977)^{66}$, o la de Maxine Berg (1985) ${ }^{67}$, prestaron atención a la distribución del trabajo familiar en razón de sexo y edad en la sociedad preindustrial. Para aquellas economías, donde la subsistencia no dependía solo de la propiedad y la producción agraria, sino del beneficio diferencial que las familias obtenían de otras actividades productivas, la industria rural por ejemplo, en la que se empleaba toda la fuerza de trabajo de la familia, y en especial la de las mujeres, los autores referidos, especialmente Berg, establecían una relación directa entre las responsabilidades laborales de las mujeres, que con cierta frecuencia modificaban la distribución sexual del trabajo, y los cambios producidos en el comportamiento social y cultural de hombres y mujeres perceptibles en las actitudes frente al consumo, las relaciones sexuales o el matrimonio. En particular se señalaba la existencia de indicios de una modificación en el comportamiento de estas mujeres que ya no se inhibían ante ciertas formas de participación social activa -participación en revueltas, cambio en los patrones de consumo, o transformación de las relaciones de pareja- y que habían supuesto un cierto debilitamiento de la autoridad patriarcal ${ }^{68}$. Aun así y a pesar de la importancia del trabajo femenino en la producción manufacturera de regiones protoindustrializadas como el caso del oeste y norte de Inglaterra, e incluso de su condición de mano de obra especializada, flexible y capacitada en algunos subsectores como el hilado de la lana o la fabricación del lino, los salarios de las mujeres fueron siempre menores que los salarios masculinos más bajos. Esto era, según apuntaba Berg, salvo en el caso de un pequeño grupo de mujeres, las mujeres solas, aquellas que por circunstancias de la vida, viudez, abandono del marido, o bien por elección propia, pasaban a constituirse en jefas de familia. El

65. De hecho, Clark utilizaba también como fuentes testimonios de vida, libros de contabilidad de familias y correspondencia familiar.

66. Kriedte, P., Medick, H., Schlumbohm, J.: Industrialización antes de la Industrialización. Barcelona. Crítica, 1976.

67. Berg, M.: La era de las manufacturas, 1700-1820. una nueva historia de la Revolución industrial británica. Barcelona, Crítica, 1987.

68. Riedte, P., Medick, H., Schlumbohm, J.: Industrialización, op. cit., pp. 98-100 y Berg, M.: La era de las manufacturas, op. cit., pp. 145-169.

(C) Ediciones Universidad de Salamanca / ®®@ Stud. his., H. ${ }^{a}$ mod., 38, n. 2 (2016), pp. 237-285 
desconocimiento de estos hogares, sin embargo, según el autor, apenas permitía unas intuiciones, reflejadas en ocasiones en la mirada de sospecha y de denuncia que autoridades y otros poderes mediáticos vertían contra ellas ${ }^{69}$. Efectivamente, si una línea de análisis sobre el trabajo de las mujeres se orientaba, tanto en la historiografía feminista como en la historia social de inspiración marxista, hacia el análisis de las características del trabajo femenino en las economías preindustriales, la relación sistémica entre capitalismo y patriarcado ${ }^{70}$ y el impacto que el capitalismo industrial había tenido en las condiciones laborables de las mujeres ${ }^{71}$, otra línea fecunda se fue abriendo en torno a la relación entre el trabajo y el desarrollo de la conciencia de los derechos o conciencia feminista ${ }^{72}$, así como de la valoración que las propias mujeres hacían de sí mismas como trabajadoras en sus respectivas familias ${ }^{73}$, a uno y otro lado del Atlántico. En la mayoría de los casos los estudios corresponden al $\mathrm{xIX}^{74}$, sin embargo, no falta alguna investigación inspiradora que aborda el tema de la articulación de los planos familiar y laboral en la vida de las mujeres de los siglos XVI, XVII y XVIII ${ }^{75}$, a partir de análisis de fuentes diversas, ahondando en las distintas capacidades que mostraron las mujeres, especialmente las de los sectores populares, para romper con los estereotipos de género. En ese sentido, a la hora de comprender la vida de estas mujeres solas es importante tener en cuenta los propios límites de las fuentes y diversificar los registros documentales a fin de obtener trayectorias de vida comprensibles a la luz de circunstancias muy variadas.

En los escritos de demanda contenidos en las requisitorias, la estrategia discursiva pasa por una lógica de victimización de las propias mujeres, inherente, de un lado, a los valores de los que las leyes de repatriación de maridos ausentes

69. BerG, M.: op. cit., pp. 169-170.

70. ScotT, J. W., Tilly, L. S.: Women, Work and Family. Nueva York, Holt-Rinehart and Winston, 1978 y Hartmann, H.: "Capitalism, Patriarchy and Job Segregation by Sex», Sings 1, 9, 1976, pp. 137-139 y «The Family as the Locus of Gender, Class and Political Struggle: the Example of Housework», Sings, 6, 3, 1981, pp. 366-394.

71. Alexander, R.: «Women's Work in Nineteenth-Century London: A Study of the Years 1820-50», en Mitchell, J. OAKley, A. (Eds.): Rights and Wrongs of Women. Harmondsworth, Penguin, 1976.

72. Liddington, J., Norris, J.: One Hand Tied Behind Us: The Rise of the Women's Suffrage Movement. Londres, Virago, 1978.

73. Stansell, Ch.: City of Women: Sex and Class in New York, 1789-1860. Nueva York, Knopf, 1986.

74. Tilly, L., ScotT, J.: «Women's Work and the Family in Nineteenth Century Europe», Comparative Studies in Society and History, 17, 1975, pp. 36-64.

75. Mendelson, S. H., Crawford, P.: Women in Early Modern England, 1550-1720. Oxford, Clarendon Press, 1998, esp. caps. 5 y 6.

(C) Ediciones Universidad de Salamanca / ®@ Stud. his., H. ${ }^{a}$ mod., 38, n. 2 (2016), pp. 237-285 
MARÍA JOSÉ DE LA PASCUA SÁNCHEZ

«A LA SOMBRA» DE HOMBRES AUSENTES:

MUJERES MALCASADAS EN EL MUNDO HISPÁNICO DEL SETECIENTOS

son hijas y de otro, a la necesidad por parte de las demandantes de forzar la efectividad del propio dispositivo. Podríamos decir que, en estos casos, las mujeres se mostraban cómplices del discurso patriarcal sobre identidades de género en aquello que hacía referencia a los papeles familiares de hombres y mujeres y su razonamiento, en la presentación de sus circunstancias ante el juez, se exponía más bien de forma retórica esperando una deducción de sentido común. Sería algo como: deduzca usted mismo mi situación, siendo mujer sola, sin la sombra de un marido que vele por mí. Y si bien es lógico pensar que las vivencias de estas mujeres en las distintas etapas de su vida habrían estado marcadas por los estereotipos de género, también lo es concluir que viviendo (sola) se aprendía a vivir, ocupándose de la subsistencia, a subsistir, dirigiendo el hogar, a dirigir, etc. Así, las conclusiones sobre pobreza, subsistencia al límite, trabajos precarios y vida en soledad que se desprenden del análisis de estos expedientes, constituyen una parte de la realidad de estas mujeres, pero no toda.

Obviamente no todas las mujeres de ausentes fueron abandonadas por sus maridos ${ }^{76}$. No obstante, la elección de un año, 1750, con notable movimiento a Ultramar y dentro del periodo que reúne un mayor número de partidas de maridos ausentes y de requisitorias tramitadas desde el obispado gaditano, me ha parecido útil para hacer una prospección a través de los testamentos, a fin de analizar los de mujeres de ausentes y los de sus maridos. Teniendo en cuenta que un viaje próximo suponía, en general, el otorgamiento de última voluntad por parte de aquel que emprendía viaje, se trata de valorar las condiciones de la marcha del cabeza de familia y a través de dispositivo material (declaración de bienes, nombramiento de herederos y tutores para sus hijos y otras cláusulas), romper con la imagen un tanto unilateral que las mujeres abandonadas proporcionan en las requisitorias. Cuando se preparaba la flota para las Indias, los testamentos, mejor que las licencias, documento en sí mucho más breve y menos apto para situar una acción en un contexto vital, familiar y socioeconómico, recogen la marcha de hombres casados, viudos y solteros y sus circunstancias familiares. Diversas son las de los 17 hombres casados que dejaron su testamento protocolizado en alguna de las 25 notarías que funcionan en 1750 en Cádiz y cuando están a punto de embarcar, en general, rumbo al Nuevo Mundo. Para un buen

76. En el padrón gaditano de 1773 aparecen censadas 548 mujeres con marido ausente, PAscua, M. ${ }^{a}$ J. de la: Mujeres Solas op. cit., p. 62. Para un periodo anterior y unos 200 emigrantes cordobeses, García-Abásolo estimaba que solo una cuarta parte de ellos habría olvidado a sus parientes en España, García-AbÁsolo, A.: La vida y la muerte en Indias. Cordobeses en América (siglos XVI-XVIII). Córdoba, Caja de Ahorros de Córdoba, 1992, pp. 56-68.

(C) Ediciones Universidad de Salamanca / ®®@ Stud. his., H. ${ }^{a}$ mod., 38, n. 2 (2016), pp. 237-285 
MARÍA JOSÉ DE LA PASCUA SÁNCHEZ

«A LA SOMBRA» DE HOMBRES AUSENTES:

MUJERES MALCASADAS EN EL MUNDO HISPÁNICO DEL SETECIENTOS

número de ellos, el viaje estaba justificado por su propio oficio ${ }^{77}$, aunque la mayor parte de los testadores no oculta que llevaba mercancías para su venta alli ${ }^{17}$. Salvo excepciones, estos hombres nombraban como tutoras-curadoras de las personas y bienes de sus hijos a sus esposas, y en caso de no tenerlos y estar sus padres vivos, dejaban a las mismas algún legado o el quinto de su fortuna. Es lo que hace Pedro de Lizárraga, natural de Motrico en Guipúzcoa, que preparaba su viaje a Buenos Aires, a donde llevaba distintas mercaderías pertenecientes a diferentes individuos. Este comisionista poseía en su tierra varios censos a favor impuestos sobre fincas que deseaba disfrutara su esposa mientras viviera y a la muerte de esta su suegra; solo por fallecimiento de ellas, su familia -primo y sobrinos-, que eran sus herederos, entrarían en el goce de dichos censos ${ }^{79}$. Domingo Viguera, natural de Cenzano-La Rioja, preparaba su marcha hacia el Puerto del Callao y declaraba llevar distintas mercancías por valor de unos 50.000 reales en cuatro cajones distribuidos en tres navíos. Nombraba por heredera a su esposa, Teresa Ladrón de Guevara ${ }^{80}$. El sevillano Juan Francisco de Cabrera, que se disponía a

77. Mateo A. Bonilla, natural de Villa Robledo-La Mancha, embarca hacia la Mar del Sur, como escribano del navío S. Ignacio de Loyola, deja esposa con una hija y esperando otro hijo (Archivo Histórico Provincial de Cádiz [en adelante AHPC], libro 766, fols. 794-795); Luís Fort, natural de Cartagena-Levante, viaja como capitán de navío al Puerto de la Ssma. Trinidad de Buenos Aires, dejando esposa y una hija (Idem, libro 4959, fols, 91-92), Francisco Martín, natural de Castilleja de la Cuesta-Sevilla, se dispone a viajar a Veracruz con plaza de despensero en el navío «El Oriente» y deja esposa e hijo en Puerto Real (Idem, libro 4959, fols. 382-382) y el marqués de Casina, Juan M. Cayetano Pérez de Alderete, teniente de navío de la Real Armada, otorga su testamento cuando se halla próximo a embarcar hacia Galicia. Tenía esposa y cuatro hijos (Idem, libro 5543, fols. 103-105).

78. Era, entre otros muchos, el caso de Servando Rodríguez, natural de Cádiz, que va a Veracruz en el navío «El Oriente», como despensero y que aprovecha los viajes para comerciar -en ese viaje llevaba 800 pesos en encomiendas de diferentes personas-. En el momento de emprenderlo sus bienes consistían en dos casas, una de ellas una casa-horno que tenía arrendada con todos sus utensilios. Dejaba mujer e hija, nombraba tutora de los bienes de esta a su esposa y le encomendaba que si él fallecía cuidara de su hermana (Idem, libro 766, fols. 682-684). Un mes antes era Narciso Basedas, natural de Moret-Principado de Cataluña y casado con una antequerana, quien otorgaba conjuntamente testamento con su esposa. Embarcaba en el navío «La Real Familia», como patrón de bote y declaraba que todo lo que tenían procedía de las «diligencias» en las que se empleaba en sus viajes a Indias. El Rey le debía 900 pesos (unos 13.500 reales) de sueldos atrasados y dejaba deudas en contra por valor de 800 pesos (12.000 reales). No tenían hijos, así que él nombraba por heredera a su esposa y esta a sus padres, que estaban vivos, y por su falta a su marido (Idem libro 766, fols. 586-589). También Manuel Méndez, natural de Berlanga-Soria, viajaba a Indias con el ánimo de comerciar, aunque afirmaba no poseer capital. Nombraba herederos a sus padres y a su esposa legaba el $1 / 5$ de sus bienes «por el cariño que le tenía», Idem, libro 1026, fols. 81-82.

79. Idem, libro 1170, fols. 9-15.

80. Idem, libro 3777, fols. 267-268.

(C) Ediciones Universidad de Salamanca / ®@ Stud. his., H. ${ }^{a}$ mod., 38, n. 2 (2016), pp. 237-285 
MARÍA JOSÉ DE LA PASCUA SÁNCHEZ

«A LA SOMBRA» DE HOMBRES AUSENTES:

MUJERES MALCASADAS EN EL MUNDO HISPÁNICO DEL SETECIENTOS

embarcar en la fragata Nuestra Señora de los Dolores, con destino a Tierra Firme, también llevaba mercancías. Dejaba en Cádiz mujer y dos hijas, estas últimas sus herederas ${ }^{81}$ y el arcense Marcos Amesquita que iba a Veracruz, cedía sus bienes a su esposa ${ }^{82}$. Otros residentes en Cádiz, por lo tanto ausentes de sus hogares donde permanecían sus mujeres solas, como Hugo Lossieux de la Vallèe, natural de Saint Malo-Francia, que emprendía viaje como piloto del navío «La Amable María» con rumbo a la Mar del Sur ${ }^{83}$, o el londinense Guillermo Ley hacían lo propio. Este último, escritural de la casa de Hugo Hancock, se hallaba enfermo y dependiendo de la caridad de su empleador. Rogaba le perdonasen algunas deudas adquiridas y dejaba por heredera a su esposa ${ }^{84}$. Aunque este fuera el tono general, los testamentos también dejan silencios solo comprensibles en casos de separación matrimonial o de mala relación de la pareja. El marsellés Juan Francisco Vernet, se declaraba casado, única referencia a este hecho en su testamento. Nombraba por heredera a su hija legítima de cuyo nombre no se acordaba ${ }^{85}$. Pedro Manuel de Ysasy, vizcaíno, vivía en Lambayeque (Perú), donde volvía después de pasar un tiempo en Cádiz. De su paso por la ciudad quedó su testamento y la declaración de herederos a sus cinco hijos. Ninguna alusión a su esposa ${ }^{86}$. También viajaban este año de 1750, en muchos de estos navíos, otros hombres solteros y viudos y algunos de los que tenían ese propósito no habían logrado embarcar ${ }^{87}$ o se habían quedado por el camino ${ }^{88}$. Ese fue el caso de Juan Francisco de Peña, natural de Vera-Navarra, que redacta su testamento cerrado autógrafo en octubre de 1750 cuando está próximo a viajar a Nueva Veracruz en el navío «El Soberbio». Explicaba la redacción de un testamento cerrado porque había contraído matrimonio «bajo sigilo y con las dispensas necesarias» en El Puerto de Santa María, hacía tres años. No daba las razones de este matrimonio secreto. Sí que su madre vivía en su localidad de origen (Vera), que su esposa no había aportado dote alguna y que tenía dos hijos, el mayor de año y medio y el pequeño de 6 meses. Tampoco

81. Idem, libro 3777, fols. 152-154.

82. Idem, libro 3837, fols. 103-104.

83. Dejaba por heredera a su hija y por tutora a su esposa, ldem, Libro 1842, fols. 973-974.

84. Idem, libro 1842, fols. 1190-91.

85. Idem, libro 3132, fols. 51-52.

86. Idem, libro 5339, fols. 401-403.

87. Christian Laurenti, nacido en Hoyer, en las cercanías de Hamburgo, estaba en Cádiz como capitán de un navío holandés fondeado en su puerto. Enferma y muere en la ciudad después de redactar su última voluntad, dejando por heredera a su esposa, Idem, libro 5339, fols. 496-497.

88. Pedro de Selaya, contador de navío en la Real Armada, falleció a bordo del navío que regresaba de La Martinica a España, el 30 de abril de 1750. Nombraba heredero a su hijo y tutora a su esposa, Idem, libro 2173, fols. 173-174.

(C) Ediciones Universidad de Salamanca / ®®@ Stud. his., H. ${ }^{a}$ mod., 38, n. 2 (2016), pp. 237-285 
MARÍA JOSÉ DE LA PASCUA SÁNCHEZ

«A LA SOMBRA» DE HOMBRES AUSENTES:

MUJERES MALCASADAS EN EL MUNDO HISPÁNICO DEL SETECIENTOS

ofrecía noticias sobre su caudal (dependencias, créditos y débitos) para cuyo conocimiento remitía a sus libros y papeles. La necesidad de mantener en secreto su matrimonio puede estar en relación con una probable dedicación al comercio por cuenta de otros o como dependiente de alguna casa comercial, algunas de las cuales establecían estas cláusulas restrictivas para sus empleados. Nombraba como tutora de las personas y bienes de sus hijos a su esposa, y por lo que sabemos muere en los meses siguientes, probablemente durante la travesía, puesto que su testamento es abierto en el mismo año de $1750^{89}$. No todos aquellos que partían, obviamente, lo hacían con la voluntad de no dejar a su familia desamparada, y los testimonios de hombres que arrancan la licencia a su esposa tras una paliza o llevándose su dinero también aparecen entre las mujeres de ausentes ${ }^{90}$. Las referencias que quedan en los protocolos de Cádiz son tan numerosas que solo a partir de muestras puede emprenderse una aproximación analítica de sesgo cualitativo a la situación familiar de estos emigrantes a la América Hispana.

Los testamentos, aunque sean mayoritariamente abiertos, conformados a partir de la declaración oral ante un notario, como el escrito de demanda de una Requisitoria lo es para su presentación ante un juez, no solo son depósitos de datos -circunstancias y objetivos del viaje, destino, situación familiar del emigrante- sino que pueden considerarse como soporte documental de un «relato de vida». Por tanto, una fuente apropiada para acceder a la reflexión que sobre la vida propia hacen los testadores. En los que hemos visto, testamentos de hombres que emprenden un largo viaje, pinceladas autobiográficas perfiladas en un momento en el que sus otorgantes se sienten protagonistas y dueños de su futuro. Entre estos y los de las esposas de los ausentes, hay diferencias significativas. Generalmente, cuando ellas los otorgan, por enfermedad, edad avanzada o, simplemente, porque hace muchos años que no tienen noticias de sus esposos y creen que es hora de dejar bien establecidos sus derechos y los de sus hijos legítimos, su perspectiva es muy diferente. Ellas no se enfrentaban al vértigo apasionante de un destino nuevo, sino más bien a un pasado y, probablemente, al peso inmovilizante de ese pasado en su vida. Pero son estos últimos los que más nos interesan como puerta de acceso a la construcción individual de sentido que estas mujeres «solas» ensayan sobre sus propias experiencias. Como señala A. Gurevich, a pesar de su carácter estereotipado, el testamento ofrece en muchas de sus clausulas una prueba imparable de

89. Idem, libro 1842, fols. 96-98.

90. La mayoría de los maridos requeridos estaban ausentes sin licencia; de las 290 de mujeres que reclaman a sus esposos entre 1675 y 1804, solo 34 declaran haber otorgado licencia, PAsCUA, M. J. de la: Mujeres Solas, op. cit., pp. 213-215.

(C) Ediciones Universidad de Salamanca / ®@ Stud. his., H. ${ }^{a}$ mod., 38, n. 2 (2016), pp. 237-285 
individualismo $0^{91}$, , si se prefiere, de individualidad significada en el propio acto de testar. En ellos, la construcción narrativa del yo que procede de la ordenación de los hechos más significativos de la existencia, se hace visible a partir de las diferentes disposiciones de tipo espiritual y material. Al igual que sucede con otras investigaciones que utilizan como metodología la dirección cualitativa y la técnica del relato de vida, en particular, la crítica de la fuente se detiene, a menudo, en las dudosas posibilidades de generalización de un estudio basado en un «único testigo». En este caso, independientemente de la disponibilidad de acceder al cuadro general a partir de una perspectiva singular, algo obviamente factible a partir de un colectivo que comparte algunas características respecto a su situación, más que a los condicionantes -sociales, económicas, vitales- generales del grupo de mujeres abandonadas, mi interés se centra específicamente en la perspectiva propia y singular que ellas asumen sobre sus circunstancias y sus propias posibilidades a fin de ir completando ese espacio de inteligibilidad en el que sus vidas habían transcurrido. La fuente, según entiendo, se revela como especialmente apta para acceder a la representación que estas mujeres se hicieron sobre su situación como mujeres solas y las capacidades que habían demostrado para articular, en condiciones adversas, su propia vida y las distintas dimensiones de su existencia. Verbalizar las experiencias, narrarlas propiamente, en el contexto de valoración casi finalista que otorga al testamento la cultura de las prácticas de la muerte de la época, nos las presenta como individuos singulares. Con una singularidad en la que no necesito buscar más allá de la ilusión biográfica $^{92}$, sino más bien situarme en el centro mismo de ella. Precisamente por el tipo documental que le da soporte; es decir, un relato construido en dialogo con los modelos sociales de comportamiento y donde la ficción de la unidad de la vida y del propio yo se mantiene básicamente a partir del mandato inherente al concepto de responsabilidad de los propios actos. En los testamentos, la historia de vida es pergeñada desde la doble ilusión biográfica que lleva a estas mujeres a ordenar los hechos más relevantes de la misma en una secuencia cronológica marcada por los ritos sociales de paso y alrededor de una identidad soportada por el nombre; ambos anclajes hijos de la convención social. Además de la posibilidad de encarar perspectivas que no pueden afrontarse en investigaciones cuantitativas, los relatos de vida ayudan al historiador a comprender la diacronía en la perspectiva del tiempo individual de una vida, las lógicas de la actuación a nivel individual, las

91. GuREvich, A.: Los orígenes del individualismo europeo. Barcelona, Crítica, 1997, pp. 91-98.

92. Bourdieu en su propuesta de superar la pugna objetivismo/subjetivismo plantea el tema de la ilusión sobre la unicidad de la biografía, Bourdieu, P.: «L'illusion biographique», Actes de la recherche en Sciences Sociales, 62, 62-63, 1986, pp. 69-72.

(C) Ediciones Universidad de Salamanca / ®®@ Stud. his., H. ${ }^{a}$ mod., 38, n. 2 (2016), pp. 237-285 


\section{MARÍA JOSÉ DE LA PASCUA SÁNCHEZ \\ «A LA SOMBRA» DE HOMBRES AUSENTES: \\ MUJERES MALCASADAS EN EL MUNDO HISPÁNICO DEL SETECIENTOS}

tácticas y estrategias que se ponen en marcha, las posibilidades de transformación real que tienen los individuos, en fin, las dinámicas de la experiencia articuladas en una transacción entre las presiones del entorno y la propia voluntad. En definitiva, como sugería Natalie Z. Davis, estaríamos ante una morfología del pensamiento y sus prácticas individuales a la luz de una cultura concreta ${ }^{93}$. Todo ello siempre y cuando se ponga orden en la investigación teniendo en cuenta una serie de supuestos básicos. Así los hechos, en realidad vividos «caóticamente» -la vida no es lineal según aprendemos a representárnosla-, se ordenan en el pensamiento y en los distintos soportes documentales de los relatos de vida de acuerdo con las diferentes lógicas que presiden estos documentos y conforme a los objetivos, conscientes o simbólicos, de quienes los utilizan. En este sentido, no podemos leer las demandas de las requisitorias de igual manera que los testamentos o las cartas. También es preciso tener en cuenta que, aunque asumamos la perspectiva individual en el análisis, los individuos viven en un contexto histórico y están inmersos en redes familiares y sociales muy amplias ${ }^{94}$.

El relato de vida en los testamentos de mujeres con marido ausente, la narración propiamente dicha con la que describen su particular condición de mujer casada, es más breve que la que aparece en las requisitorias. Al fin, en estos casos, lo que interesa es simplemente dejar constancia del hecho y de sus consecuencias legales. Catalina de Villar y Zeijas, gallega que servía en una casa de Cádiz; pedía a sus «amos» que le favorecieran en la muerte, como habían hecho en vida y pagaran su entierro porque no tenía bienes. Su marido se había marchado hacía más de 20 años y de aquel matrimonio no habían quedado hijos. La declaración de estas circunstancias es brevísima y rotund $\mathrm{a}^{95}$, no hay lugar para las lamentaciones ni los reproches; en este caso ni siquiera para pedir explícitamente lo que le pertenece, aunque por el tenor de la misma quede claro su derecho a la mitad de los gananciales. Pensando en ello, tal vez, deja por heredera a la hermana de su patrono, en cuya casa vive y miembro de ese pequeñísimo grupo de personas que parecen

93. Davis, N. Z.: «Las formas de la Historia Social», Historia Social, 10, primavera-verano 1991, pp. 177-182, p. 179.

94. El sociólogo Daniel Berteaux, que sigue el método de la Escuela de Chicago en el análisis de los documentos personales, propone considerar tres aspectos fundamentales: la realidad histórica a tenor de las situaciones objetivas de los sujetos, la realidad psíquica y semántica o lo que el sujeto piensa/sabe y la realidad discursiva del relato o lo que el sujeto cuenta, Le récit de vie. París, Armand Colin, 2006.

95. Declaro habrá tiempo de 20 años, poco más o menos, contraje matrimonio (...) con Manuel J. de Castro, que a los cinco meses se embarcó para los reinos de Indias donde al presente se halla con caudal considerable adquirido después de contraído el dicho matrimonio, por cuanto al tiempo que se contrajo ni el dicho mi marido ni yo llevamos a el cosa alguna. De cuyo matrimonio no hemos tenido hijos en AHPC, libro 3118, año 1707.

(C) Ediciones Universidad de Salamanca / ®@ Stud. his., H. ${ }^{a}$ mod., 38, n. 2 (2016), pp. 237-285 
MARÍA JOSÉ DE LA PASCUA SÁNCHEZ

«A LA SOMBRA» DE HOMBRES AUSENTES:

MUJERES MALCASADAS EN EL MUNDO HISPÁNICO DEL SETECIENTOS

constituir su propio y único universo social, toda vez que sus padres habían fallecido en un lugar de Galicia cuyo nombre no recordaba ${ }^{96}$. Muy parecidas circunstancias son las de Ana Ibáñez Ramírez, viuda de un ausente fallecido en el mar. Solo tuvo un hijo, muerto también de menor edad. La historia de su vida, breve en estas tristes coordenadas familiares, se detiene algo más en las sociabilidades trenzadas en las casas en las que ha servido. La primera fue la casa de un presbítero que al fallecer le dejó por los días de su vida el usufructo de la mitad de una casa que tenía arrendada, aunque le debían mas de un año de alquiler; en la segunda casa, en la que asiste en el momento de otorgar testamento, dice que se hallan por caridad. Dispone un entierro humilde y deja por heredero de sus bienes a su patrono. El servicio doméstico era un medio frecuente de supervivencia de estas mujeres de ausentes, como en general de las mujeres solas. La economía gaditana del setecientos, con un sector primario prácticamente inexistente y un secundario extremadamente débil, empujaba a la potencial población activa más débil hacia actividades de los servicios, un subsector hipertrofiado. Servir era un modo de hacer frente a las necesidades básicas de techo y comida cuando no se disponía recursos propios. Micaela Fernández, vecina de Cádiz, era una de estas mujeres. En su caso, el relato de vida en aquellos aspectos relacionados con su matrimonio también muy breve, se limita a la declaración de desconocimiento sobre la localización de su marido, ausente en Indias ${ }^{97}$. Mantenía una sólida amistad de mutuo apoyo con otra mujer que servía en la misma casa. De hecho, los escasos bienes que tenían los compartían (imágenes y láminas de santos, rosarios y algunos cubiertos de plata). Dejaba por heredera a su amiga, lo mismo que esta hacía con ella en un testamento otorgado en el mismo día y en ambos casos con idéntico destino para el caso de un supuesto fallecimiento de la heredera: el Colegio de madres nazarenas de Jerez de la Frontera ${ }^{98}$. A pesar de estar también sin bienes, la antequerana Petronila María de Velasco, que vivía en Cádiz desde hacía 4 años con su hija de 20 años, no da detalles sobre sus fuentes de subsistencia. Casada desde hacía 26 años, su marido llevaba ausente en Indias 8 o 9. Otro hijo suyo estaba con él. Sí declara que, al tiempo del matrimonio, ella llevó dote, su marido no llevó capital y los gananciales que había al tiempo de su partida se los llevó con él. Sus bienes presentes se limitaban a los muebles y adornos de la pequeña casa que habitaba, compuesta de sala y alcoba y algunas cantidades que le debían, pero tenía una deuda de 300 reales que rogaba a su hija pagara si podía ${ }^{99}$. Aunque

96. Ibidem.

97. Idem, libro 2549, año 1750, fols. 60-62.

98 Idem, fols. 63-65. Testamento de M. ${ }^{a}$ Eusebia de los Reyes, soltera.

99. Idem, libro 3587, año 1702, fols. 178-180.

(C) Ediciones Universidad de Salamanca / ®®@ Stud. his., H. ${ }^{a}$ mod., 38, n. 2 (2016), pp. 237-285 
podemos encontrar, entre los testamentos, otros casos de tenor semejante, donde las mujeres de ausentes explican o dejan entrever dificultades de supervivencia, en la línea en la que señalan la mayoría de las requisitorias, lo cierto es que las condiciones generales de las mismas se hallan más diversificadas, obteniéndose un porcentaje mayor de mujeres que podrían encuadrarse en los sectores medios. Puede tratarse, en parte, del resultado divergente de análisis en distintos momentos de la vida de estas mujeres y de la influencia del paso del tiempo en aquellas testadoras con cierta edad, entre las que la ausencia del marido se ha alargado tanto que ellas han construido una vida al margen. En cualquier caso, el trabajo y una cierta actitud de emprendimiento parecen estar sobre la base de un mayor desarrollo de autonomía. Es el caso de una jerezana, Francisca Rodríguez, quien también despacha brevemente la historia de un matrimonio en el que no intervino ni dote ni capital y fue interrumpido pronto por la marcha de su cónyuge a Indias ${ }^{100}$. La diversificación de sus fuentes de subsistencia ofrece la clave de la acumulación de una pequeña fortuna, obtenida, según ella «con su industria y trabajo». Aquella consiste en algunas alhajas de oro y diamantes y 3.000 reales en dinero en efectivo. Ha trabajado en el servicio doméstico - de hecho hace un legado de 12 cubiertos de plata a su señora-, también sabemos que se ha dedicado a labrar chocolate y, por sus deudas a favor, unos 825 reales distribuidos en pequeñas cantidades, deducimos que ha empleado parte de su fortuna en el pequeño préstamo de consumo. En su testamento aparecen dos de los ejes que se revelan como el principal apoyo de estas mujeres de ausentes: el trabajo y las solidaridades nacidas en sus círculos familiares, de amistad y de vecindad. Francisca, como otras muchas, hace legados, en este caso de joyas, a diferentes mujeres ${ }^{101}$, un par de legados a dos hombres de su círculo de amistades ${ }^{102}$ y 300 reales además de «todo lo que se necesita y ella tiene para labrar chocolate» a una viuda ${ }^{103}$. Como otras también, Francisca no sabía escribir, pero da muestras de una excelente capacidad para contar su vida y significarla más allá de un matrimonio fracasado. Ambos apoyos, familia-amigos y trabajo se repiten como ejes del relato de vida que hacen las mujeres de ausentes en aquellos momentos en que, enfermas o con edad avanzada, temen una muerte próxima. Josepha Pabón, natural de Osuna, cuyo marido llevaba ausente en Indias 25 años sin enviar ningún tipo de socorro, vivía con su

100. Idem, libro 3132, año 1749, fols. 50-52.

101. Reparte entre cinco mujeres, un aderezo de oro y diamantes, otro de oro y esmeraldas, unos zarcillos de oro y diamantes, una imagen de san José de oro y diamantes, una sortija de oro con 7 diamantes, Ibidem.

102. Unos botones de oro a uno, una cajeta de plata a otro, Ibidem.

103. Ibidem. 
madre. Sus bienes se reducían a la ropa de su uso, el menaje de casa y «algunas prendecitas» de oro y plata que habían adquirido «con su industria y trabajo», además de los que le pudieran corresponder por legítima materna ${ }^{104}$. También vivía con su madre María de Perea, natural de Cádiz, con marido ausente en Veracruz ${ }^{105}$. En este caso, se añadía la compañía de una hija a la que nombraba por heredera de unos bienes propios, heredados de su padre, de los que no daba más noticias. Josefa María García de Luque ${ }^{106}$ tampoco estaba sola y, después del fallecimiento de su hija al dar a luz, le quedaban su nieto y su yerno. Este su albacea, aquel su heredero. Josefa M. ${ }^{a}$ había nacido en Marchena-Sevilla y se había casado en Cádiz. Al tiempo del matrimonio había llevado como dote 2.200 reales en dinero y joyas; su marido no había aportado nada y al poco tiempo se había marchado a Honduras dejándola embarazada, sin que al presente tuviera conocimiento de si estaba vivo o muerto. Josefa no explicaba cómo había adquirido unas casas por valor de 15.000 reales, libres de tributo, que tenía arrendadas por 60 reales al mes, ni otros bienes muebles -diferentes joyas, muebles y cuadros- ${ }^{107}$. No es el caso de Leonor de Ribera, cuyo marido falleció en Indias dejándola por heredera de una casa en Cádiz y una pequeña fortuna (9.000 pesos) que aún no había recibido ${ }^{108}$. También poseía una casita en Chiclana, donde se había trasladado a vivir 4 años antes, y que no sabemos si había adquirido con lo procedido de su dote (4.500 reales) o por herencia de sus padres. Tampoco estaba sola, a pesar de que aquellos habían fallecido, así como una hija que tuvo y murió al nacer. La disposición de su herencia y sus legados revelan otros afectos trenzados a lo largo de la vida: sus dos cuñadas a las que deja las dos terceras partes de su caudal -una tercera quiere invertirla en una capellanía de misas- y un legado de 3.000 reales que destina a una niña a la que ha criado y educado ${ }^{109}$. En muchos casos esos parientes o amigos constituyen no solo una red de afecto, sino también de apoyo económico importante y las historias de algunas de estas mujeres señalan dependencias parciales o más amplias. La situación de la francesa Catalina Pradal ${ }^{110}$, con

104. Idem, libro 3132, año 1750 , fols. 42-43.

105. Idem, libro 3627, año 1750, fols. 165-166.

106. Idem, libro 1594, año 1731, fols. 75-78.

107. Ibidem.

108. Idem, libro 3612, año 1735, fols. 1269-1276.

109. Idem, fols. 1275-1276.

110. Había contraído matrimonio diez años atrás en Niza y en aquel tiempo su marido no tenía capital y ella había aportado unos 200 pesos. No habían tenido hijos ni había gananciales. Por la ausencia de dicho su marido y no tener bienes ella se hallaba a expensas de unos parientes, a quienes dejaba por herederos conforme a no haberlos forzosos (Idem, libro 3779, año 1755, s.f.).

(C) Ediciones Universidad de Salamanca / ®®@ Stud. his., H. ${ }^{a}$ mod., 38, n. 2 (2016), pp. 237-285 
MARÍA JOSÉ DE LA PASCUA SÁNCHEZ

«A LA SOMBRA» DE HOMBRES AUSENTES:

MUJERES MALCASADAS EN EL MUNDO HISPÁNICO DEL SETECIENTOS

marido ausente en Nueva Orleáns ${ }^{111}$ o de María Gertrudis Escamilla, también sin hijos, es muy significativa de estas redes de solidaridad y afecto que sirven de apoyo a estas mujeres. En el caso de esta última, su marido se había ausentado a Filipinas, y a pesar de las diligencias realizadas no había conseguido averiguar si vivía o no. En cualquier caso, los bienes que declaraba (una casa de viviendas altas y bajas en Chiclana -en la que había invertido 11.000 reales-, ropa, alhajas y menaje de casa) eran, según expresaba, propios y «adquiridos por ella sola». En esta lógica hacía legado de sus muebles a sus sobrinas y hermana, y dejaba como heredero universal a un tal Josef Masip, de quien solo nos dice que es vecino de Cádiz y del comercio. También incluye en su testamento una invocación que deberá contener cualquier testamento nuevo que otorgue para ser considerado válido ${ }^{112}$. ¿Está previniéndose por si alguien de su familia, o el marido ausente, no estaba conforme con la cláusula de herencia? La capacidad para defenderse por sí mismas, y también de emprender negocios rentables es evidente en muchas otras, cuyas declaraciones testamentarias ofrecen indicios de esos significados polivalentes que el trabajo y la actividad económica tenían para las mujeres solas. Jacoba Rossa Tuis, natural y vecina de Cádiz, viuda de un capitán de los batallones de Marina, se dedicaba al comercio y no dependía de los sueldos de su marido -la Real Hacienda le debía aún varios- para mantenerse, ya que tenía 120 pesos (1.800 reales de vellón) en metálico para este fin. Además tenía invertidos 1.400 pesos en una casa comercial, otros 414 pesos de plata doble en mercancías y géneros que viajaban a Indias junto a tres chupas que, asimismo, había embarcado y 300 pesos más que le debían. Es decir, alrededor de 33.000 reales invertidos en el comercio, además de lo que poseía en metálico para ir viviendo ${ }^{113}$. Esta pequeña fortuna y las alhajas y ropa de su uso no contempladas en el recuento anterior, le va a permitir disponer legados, unos explicitados y otros guardados bajo el secreto de lo comunicado a sus albaceas ${ }^{114}$. Más modesta, pero igualmente significativa, es la utilidad que la sevillana Ana Florencia de Torres extrae de sus inversiones. A su matrimonio, 23 años atrás, había llevado por dote 200 pesos escudos en doblones de oro y otros 200 pesos escudos en ropa de su uso y alhajas (unos 6.000 reales). Su marido se había marchado a Indias poco después de la boda, llevándose su dote y sin enviar noticias sobre su paradero. En la actualidad, los bienes propios, además de la ropa de su uso, consistían en 300 pesos escudos (4.500 reales) que

111. Idem, libro 4425, año 1675 , fols. 660-662.

112. Idem, libro 3151, año 1800, fols. 238-241.

113. Idem, libro 3627, año 1750, fols. 545-548.

114. A dos primas huérfanas -2.250 reales a cada una-, a otra prima 4.500 reales, a una amiga ropa, entre otros, Idem, fol. 548.

(C) Ediciones Universidad de Salamanca / ®@ Stud. his., H. ${ }^{a}$ mod., 38, n. 2 (2016), pp. 237-285 
había dado a riesgo en la última flota para Nueva España y unas cuatro arrobas de chocolate «que utilizaba para ganarse la vida». Más allá de los bienes de esta chocolatera que invierte sus ganancias en el comercio de Ultramar, su testamento, en particular sus legados, la sitúa en una red familiar constituida por una tía y diferentes sobrinos, entre los que elige a dos sobrinas menores como herederas ${ }^{115}$. Catalina M. ${ }^{a}$ Foogt, natural de Estocolmo y vecina de Cádiz, traza también un relato de construcción de una vida autónoma y al margen de un segundo matrimonio fracasado. Viuda y con dos hijos, se había vuelto a casar, por lo que se hallaba de nuevo embarazada. Al contraer su primer matrimonio había llevado de dote 250 pesos que se habían convertido al contraer segundo matrimonio en 9.000 reales en dinero y diferentes géneros de una tienda de encajes que había adquirido. De su marido solo nos dice que no sabe el capital que llevó al matrimonio, pero que, en cualquier caso, el que pudo tener «se lo llevó a Indias sin dejarle ningún dinero para su manutención». En el momento en que redacta su testamento tiene en deudas a favor 16.620 reales y en su tienda de ropa y encajes mercancías por valor de 61.300 reales. Aunque es verdad que estas mercancías las debe, también lo es que no declara a cuánto asciende el total de su caudal ${ }^{116}$. Ana de Espino, también casada con marido ausente, dispone su testamento dejando bien claro su autonomía. Afirma que cuando contrajo matrimonio, 24 años atrás, ni ella aportó dote ni su marido capital alguno y que los bienes que tiene «son adquiridos por ella», puesto que su marido solo hizo con ella 4 meses de vida en común y se marchó sin siquiera advertirla. Ella ha criado en su casa a una sobrina beneficiaria única de su herencia y de algún legado, entre ellos, de la esclava que tiene $^{117}$. Serafina Lifandi, con marido ausente en Indias, deja por heredera de unos bienes «que son suyos»-puesto que cuando contrajo matrimonio ninguno de los aportaron dote o capital-y que ascienden a 22.500 reales en efectivo, además de algunas alhajas, la ropa de su uso y muebles y menaje de casa, a su única hija ${ }^{118}$.

La débil frontera que separa en muchas ocasiones la situación de la mujer con marido ausente de la malcasada puede percibirse también a través de los testamentos en los que la discreción no puede sofocar algún silencio clamoroso ${ }^{119}$, o

115. Idem, libro 2540 , año 1725 , fols. 295-298.

116. Idem, libro 4246, año 1700 , fols. $28-31$.

117. Idem, libro 4425, fols. 660-662.

118. Idem, libro 1362, año 1800, fols. 288-291.

119. El testamento Tomasa Micaela Barea, de 26 años, es indicativo de estas circunstancias. Casada en segundas nupcias, nada más dirá con respecto a su esposo. Explica que se hallaba en la casa de don Joseph Befigan, al que asistía voluntariamente por haberla aliviado en sus necesidades. También declaraba que era propietaria de una tercera parte de una casa heredada de sus padres, por valor de 1.000 pesos escudos. En la cláusula de herencia figura como única

(C) Ediciones Universidad de Salamanca / ®@ Stud. his., H. ${ }^{a}$ mod., 38, n. 2 (2016), pp. 237-285 


\section{MARÍA JOSÉ DE LA PASCUA SÁNCHEZ \\ «A LA SOMBRA» DE HOMBRES AUSENTES: \\ MUJERES MALCASADAS EN EL MUNDO HISPÁNICO DEL SETECIENTOS}

las noticias nos llegan a través de declaraciones de ellas ${ }^{120}$ o de los esposos ${ }^{121}$. Pero la ausencia, física o simbólica, del marido, el desamor o el mal entendimiento en la pareja podían provocar no solo una reclamación judicial de regreso forzoso, sino otras veces la huida de la propia mujer. Aunque no es lo usual, entre las requisitorias hay tres otorgantes masculinos que reclaman a sus esposas. Uno de ellos es Cristóbal Navarro que, según expone, estando ausente en Nueva España su mujer se había ausentado, a su vez, a Veracruz y solicitaba se la obligara a volver ${ }^{122}$. También Juan Antonio Vidal, natural y vecino de Puerto Real, interpuso en 1775 una demanda en el obispado para averiguar el paradero de su esposa, así como si esta se había portado adecuadamente en su ausencia. Exponía que se hallaba en Indias, cuando se promulgó el último decreto que obligaba a los casados ausentes y sin licencia a regresar a España (septiembre de 1774). En esas circunstancias, argumentará, tuvo que malvender sus bienes con grave quebranto de los mismos, además, cuando regresó su esposa había abandonado el domicilio conyugal. Completa su petición con la de licencia para volver a irse y arreglar todo lo que dejó pendiente en Indias ${ }^{123}$. El tercer caso es el de Manuel Guerrero, natural de Lepe, de oficio marinero, quien presentará, en el plazo de dos meses del año 1737 y en el obispado de Cádiz, dos demandas reclamando a su mujer. Esta, según argumenta, tras siete años de matrimonio «sin motivo ni causa», quería separarse. Él acudió al Vicario, quien solicitó la comparecencia de su mujer a fin

beneficiaria su alma, para que sus bienes sean distribuidos en fines piadosos (Idem, libro 5745, año 1750, fols. 63-64). Por su parte, Elvira Chanelo declara no recordar la dote que llevó a un matrimonio del que hubo hijos que murieron. Propietaria de dos casas y ajuar doméstico y joyas, no encontramos en su testamento ninguna otra mención a su marido, que no figura ni como albacea ni como heredero. Nombra por tales a sus sobrinas, no sin antes efectuar un importante legado a una mujer viuda que la ha asistido y a la que lega una casa con todo lo que contiene y unas pulseras. Además advierte a sus herederas que si ponen pleito a la beneficiaria de ese legado las deshereda e instituye por tal a su alma (Idem, libro 5306, año 1695, fols. 223-227). Tampoco encontramos ninguna alusión a su marido, aparte de que se había casado 58 años atrás, sin aportar bienes y sin que hubiera hijos, en el testamento de María Ximénez Granados, que se ha mantenido con su oficio de «comadre de parir» y que lega a dos hijas de una sobrina 250 pesos por los beneficios recibidos de ellas (Idem, libro 3587, año 1702, fols. 310-313).

120. La sevillana María de Guzmán estaba separada de su marido y no tenía hijos. En su testamento declara que sus bienes presentes «los ha adquirido ella sola». Deja una memoria en poder de su confesor y como herederos a sus padres (Idem, libro 1821, año 1717, fols. 195-199).

121. En este caso a través de las del gallego Martín Díaz, quien declara en su testamento que desde hace algo más de un año no hace vida maridable con su segunda esposa, "por motivos justificados». Deja por herederos a sus cuatro hijos y como tutoras de los dos menores a sus hijas mayores (Idem, libro 5745, año 1750, fols. 436-438).

122. Archivo Diocesano de Cádiz [en adelante ADC], Varios, libro 1854, año 1710.

123. Idem, libro 1856, año 1775.

(C) Ediciones Universidad de Salamanca / ®@ Stud. his., H. ${ }^{a}$ mod., 38, n. 2 (2016), pp. 237-285 
MARÍA JOSÉ DE LA PASCUA SÁNCHEZ

«A LA SOMBRA» DE HOMBRES AUSENTES:

MUJERES MALCASADAS EN EL MUNDO HISPÁNICO DEL SETECIENTOS

de aconsejarla, momento que ella aprovechó para huir. Declara que sabe que su esposa está en casa del cura de la parroquia de Santiago, en la vecina localidad de Jerez de la Frontera y solicita un auto de requisitoria para que sea devuelta a su compañía. Por las declaraciones, se intuye la causa de la huida de la mujer, y tras del lugar que ha buscado como refugio, una «casa honrada», la voluntad de iniciar los trámites de separación. Al día siguiente de la demanda, y por exigencia del Provisor, el marido exhibe la copia de una fianza que ha otorgado ante notario con el compromiso de tratar bien «de obra y de palabra» a su esposa cuando esta sea devuelta a su compañía ${ }^{124}$. La segunda requisitoria es necesaria por cuanto cuando Manuel acude a Jerez junto al alguacil mayor eclesiástico a recoger a su mujer, esta se ha ido a Málaga. El nuevo auto de reclamación, de 9 de mayo de 1737, es del tenor del anterior. Sin embargo, el expediente guarda alguna sorpresa más. Cuando a Manuel se le presenta la cuenta de los 57 pesos escudos que han costado las dos requisitorias -incluido el desplazamiento a Jerez para recoger a la esposa huida-, él no quiere o no tiene con qué pagar, así que el Provisor tiene que requerirle el pago de la deuda bajo la amenaza del embargo de bienes ${ }^{125}$. Aunque en la base de muchas de estas ausencias estaban las motivaciones económicas o la razón del desempeño de oficios o cargos que exigían el desplazamiento, en otros la marcha del cónyuge era la solución buscada o procurada por uno de los esposos para finalizar con una vida de pareja no satisfactoria. Algunas de las mujeres que reclaman a sus maridos ofrecen claros testimonios de ello. Francisca de Salazar reclamaba a un marido que se ausentaba continuamente de su casa con el único propósito de «vivir a sus anchas y exento de las cargas del matrimonio» ${ }^{126}$, Sebastiana Pernia lo acusaba de huir para mantener una relación ilícita ${ }^{127}$ y Pascuala de Espinosa había localizado una carta que evidenciaba que su marido se había marchado para estar con otra mujer a la que había prometido matrimonio ${ }^{128}$. Otros, según declaraciones de estas esposas demandantes, regresaban a su patria impulsados por los conflictos con los parientes de ella ${ }^{129}$ o la pobreza ${ }^{130}$. Pero también ellas sentían frustrados sus sueños y anhelos durante el matrimonio y algunas intentaban rehacer su vida. Diversos expedientes judiciales, como los de

124. Idem, libro 1854, año 1737.

125. Ibidem.

126. Idem, libro 1854, año 1731.

127. Idem, libro 1855, año 1755.

128. Idem, libro 1856, año 1761.

129. El marido de Candelaria González, vecina de la Habana, había regresado a Puerto Real, de donde era originario, por esta causa (Idem, libro 1856, año 1771).

130. El esposo de M. ${ }^{a}$ Magdalena Márquez de Miranda volvió a su patria, Bayona, acuciado por la miseria con la que vivían en Cádiz y su avanzada edad (Idem, libro 1856, año 1767).

(C) Ediciones Universidad de Salamanca / ®®@ Stud. his., H. ${ }^{a}$ mod., 38, n. 2 (2016), pp. 237-285 
destierro ${ }^{131}$ por ejemplo, o los originados por causa de bigamia, son buena prueba de estas situaciones de mujeres de ausentes que no esperan pacientemente el regreso, sino que emprendían nuevas relaciones afectivas. Obviamente, la requisitoria no es la fuente adecuada para que estas realidades aparezcan y el cruce con otros fondos documentales en estos casos se revela muy esclarecedor. Rafaela Legur, esposa de un comerciante ausente en Cartagena de Indias decide, en 1772, solicitar el regreso de aquel. Su marido era de los que habían ido con licencia-dada por ella en el convencimiento de que era un hombre de bien y solo procuraba la mejora de la situación familiar-. Después de 11 años ella declarará sentirse engañada y convencida de que la intención de su marido era abandonar a la familia, exigiendo su vuelta «bajo partida de registro» y dándole solo un breve plazo para que pusiera «a buen recaudo sus negocios» ${ }^{132}$. Como sucede en otras ocasiones, se nos oculta el resultado de estas gestiones. Ante estas estrategias de regreso, los maridos interponían muchas veces sus propias tácticas de elusión, entre las más comunes, seguir huyendo, cambiar de nombre o sobornar a las autoridades ${ }^{133}$. Sin embargo, he aquí que localizamos a Rafaela Legur entre los procesos inquisitoriales por bigamia, acusada de conato de poligamia. Por el expediente sabemos que poco después de la petición de regreso de su esposo, tal vez porque le llegaron noticias de que no había sido localizado o se le daba por muerto -esto último es lo que ella sostiene-, entabla relación con Alejandro Cheberría, un dependiente de la Casa Comercial Subibuaga con el que contrae matrimonio secreto y tiene un hijo. Pasado un tiempo recibirá la noticia de que su primer marido aún vive, así que abandonará al segundo y, al parecer, se desplaza a Sevilla donde la vemos acudiendo al convento de Santa Clara solicitando su entrada en él como religiosa. En las conversaciones con la superiora, un día le proporciona una lista de personas que pueden informar sobre su vida y costumbres y otro, según la priora del convento que será quien la denuncie a la Inquisición, le relata ingenuamente la historia de su vida. Si nos ceñimos a su declaración, resulta que se casó por segunda vez porque había recibido noticias fiables de la muerte de su primer marido, pero cuando se enteró de que este vivía, se separó del segundo. Posteriormente, recibiría la fe de muerte del primero, pero no querrá formalizar su relación con el segundo, a pesar de que este le pide que se casen. Ella ha decidido que quiere ser monja. La abadesa se escandaliza con esta trayectoria tan poco ortodoxa, escribe

131. María Lucena, vecina de Medina Sidonia, con marido ausente en Indias, había sido desterrada al ser denunciada por sus vecinos por mala conducta. En 1660 solicitaba permiso para regresar a su domicilio (Idem, libro 1854, año 1660).

132. Idem, libro 1856, año 1772.

133. Pascua, M. J. de la: Mujeres Solas, op. cit., pp. 250-285.

(C) Ediciones Universidad de Salamanca / ®@ Stud. his., H. ${ }^{a}$ mod., 38, n. 2 (2016), pp. 237-285 


\section{MARÍA JOSÉ DE LA PASCUA SÁNCHEZ \\ «A LA SOMBRA» DE HOMBRES AUSENTES: \\ MUJERES MALCASADAS EN EL MUNDO HISPÁNICO DEL SETECIENTOS}

al confesor de Rafaela que, según esta, le ha aconsejado en ese sentido, pero el confesor, primero argumenta que no ve obstáculo en que tome el velo, pues cuando se casó por segunda vez actuó de buena fe; luego se lavará las manos y, finalmente, ante el Santo Oficio no mantendrá esta versión, limitándose a declarar que le informaron «siniestramente» ${ }^{134}$. El delito de bigamia, aunque de fuero mixto, fue perseguido fundamentalmente por la Inquisición durante los siglos XVI, XVII y XVIII. Ya en este último, a lo largo de la década que va entre 1770 y 1781, la jurisdicción real quiso imponer su monopolio sobre la persecución y castigo del mismo sin conseguirlo. Las causas tramitadas ante los distintos tribunales de distrito, o que llegaban al Consejo a través de los resúmenes de causas realizados por los relatores en el caso de las Alegaciones Fiscales, han permitido una primera aproximación al tema. Efectivamente, más allá de su frecuencia, y de la distribución temporal a lo largo de esos siglos -por lo que sabemos no fue un delito muy frecuente, aunque sí de presencia constante y con un periodo álgido entre 1550 y 1650 , probablemente debido de una mayor persecución a causa de la implantación del modelo católico de matrimonio que sale de Trento- interesa deslindar las causas de la bigamia con algo más de precisión que la tradicional distinción entre un tipo de bígamo de «buena fe» o por ignorancia, mayoritario supuestamente en un principio y el tipo de bígamo-aventurero, predominantemente masculino, hacia el que se deslizaría el perfil sociológico del encausado durante el seiscientos $^{135}$. Mi aproximación al tema a partir de la serie de Alegaciones Fiscales durante el siglo xviII y sobre 330 casos conservados, señalaba efectivamente una presencia mayoritaria de hombres (relación 75/25), si bien esta relación de masculinidad se alteraba en aquellos tribunales con mayor número de causas por bigamia, como era el de Sevilla ${ }^{136}$.

Una mala vida matrimonial marcada por ausencias temporales del esposo o la previsión del carácter definitivo de la misma por posible fallecimiento, aparece en las declaraciones de mujeres acusadas de bigamia como la razón de su iniciativa para formalizar otras relaciones. En el primer grupo se encuadra la de la valenciana María Sellés, quincallera, sin domicilio fijo, que cuenta con 45 años cuando es delatada en el tribunal de la Inquisición de Córdoba en 1767, porque su primer

134. Archivo Histórico Nacional [en adelante AHN], Inquisición, leg. 3721, exp. 18 (Tribunal de Sevilla, 1774).

135. Gacto, E.: «El delito de bigamia y la Inquisición española», en Sexo Barroco y otras transgresiones premodernas. Madrid, Alianza editorial, 1990, pp. 127-152, DeDIEU, J. P.: «Estructura de la actividad procesal del Santo Oficio", en Historia de la Inquisición en España y América, t. II. Madrid, Biblioteca de Autores Cristianos, 1984, pp. 629-632, Figueras, E.: Pervirtiendo el orden del matrimonio. Bígamas en México, siglos XVI-XVII. Barcelona, 2003.

136. Pascua, M. J. de la: Mujeres Solas, op. cit., pp. 139-189.

(C) Ediciones Universidad de Salamanca / ㅛ Stud. his., H. ${ }^{a}$ mod., 38, n. 2 (2016), pp. 237-285 
marido, del que había presentado fe de muerte -falsa-, seguía vivo. Ante las evidencias, la reo confiesa «llorando»: su marido se ausentaba continuamente y no quería hacer vida maridable con ella, a pesar de que «ella le buscaba llevando el niño al cuello» ${ }^{137}$. En el segundo grupo podemos encuadrar a Inés Guerrero, quien según propia declaración había cometido bigamia de «buena fe», convencida de que su primer marido, ausente en Indias, había muerto. Cuando se entera que vive, acude al tribunal a autodelatars $\mathrm{e}^{138}$. No obstante, si algo nos confirma el estudio de diferentes trayectorias de vida de mujeres acusadas de bigamia es de que la bigamia femenina no se agota en este modelo que tiene como eje de referencia una ausencia del esposo. Otras historias, otras protagonistas proporcionan indicios sobre la voluntad de cambiar de vida ${ }^{139}$ y también los avatares fallidos, muchas veces terribles, de mujeres inmersas en relaciones tóxicas, golpeadas por la miseria, la violencia y el desamor.

Las diversas fuentes a las que tradicionalmente se acude para analizar las rupturas de pareja, los conflictos matrimoniales y la violencia contra las mujeres, documentación básicamente de tipo judicial, nos presentan fundamentalmente a mujeres como protagonistas de las demandas. Más concretamente a mujeres malcasadas. Los pleitos relacionados con la familia eran uno de esos espacios legales mixtos en los que entendía el derecho real y el derecho eclesiástico. Para los reinos hispánicos, por real cédula de 12 de julio de 1564, la legislación del Concilio de Trento fue declarada derecho vigente. Los delitos contra la moral sexual y matrimonial eran competencia de los tribunales eclesiásticos, tanto ordinarios como excepcionales, mientras los aspectos relacionados con los bienes del matrimonio y su administración entrarían dentro de la competencia de la justicia real. Así pues, en la época, el divorcio y todos los problemas de orden moral que afectaban a la institución matrimonial era asunto de los tribunales eclesiásticos. A pesar de los conflictos entre jurisdicciones, crecientes a lo largo del XVIII, como en el caso de la bigamia o en los de separación matrimonial, especialmente cuando el tribunal eclesiástico se arrogaba un derecho que no poseía e intervenía en las cuestiones económicas del pleito, es aquí donde la historiografía española de la violencia familiar viene encontrando referencias directas y abundantes sobre el maltrato doméstico. Los procesos de divorcio descubren los malos tratos como la causa más general del recurso a la separación de cuerpos y bienes y oculta, en otros casos que conocemos, violencias mayores como intentos frustrados de asesinato. Las investigaciones realizadas sobre distintos provisoratos peninsulares nos

137. AHN, Inquisición, leg. 3723, exp. 42, año 1767.

138. Pascua, M. ${ }^{a}$ J. de la: Mujeres Solas, op. cit., pp. 147-149.

139. Idem, pp. 151-90. 


\section{MARÍA JOSÉ DE LA PASCUA SÁNCHEZ \\ «A LA SOMBRA» DE HOMBRES AUSENTES: \\ MUJERES MALCASADAS EN EL MUNDO HISPÁNICO DEL SETECIENTOS}

hablan de una realidad que, sin embargo, no es específica ni de la edad moderna ni de los países católicos ${ }^{140}$, aunque por lo que se refiere al mundo hispánico y a tenor del número de procesos incoados tiene un peso creciente en los siglos modernos. Así es en las diócesis de Barcelona ${ }^{141}$, de Pamplona ${ }^{142}$ o de Cádiz ${ }^{143}$ y su número en aumento parece estar relacionado con la sistematización de una mecánica procesal para tales causas ${ }^{144} \mathrm{y}$, aún más, con la implantación paulatina en las curias diocesanas tras el Concilio de Trento de instrumentos de control sobre la moral de los fieles, utilizados también por parte de estos como una vía de solución de sus problemas cotidianos.

Las mujeres acudieron a estos tribunales en demanda de auxilio en la creencia de que la Iglesia mediaría en un problema que era de su competencia; proporcionaría pruebas documentales que solo ella podía dar-certificaciones de matrimonio, bautismo, fe de vida y buenas costumbres, certificaciones de pobreza, etc.- $y$ facilitaría los instrumentos legales necesarios gratuitamente en casos de pobreza reconocida. De esta forma, los fondos de los archivos diocesanos han legado tipologías documentales de procesos judiciales a iniciativa mayoritariamente femenina que señalan el carácter y la dirección de los conflictos en las relaciones de pareja: las demandas de divorcio, las demandas por incumplimiento de esponsales y estupros y las demandas por abandono de hogar. En estas tres variantes están contenidas un buen número de violencias maritales y violencias sexuales; y como en un negativo los comportamientos que asumen hombres y mujeres ante los conflictos y las respuestas que tanto ellos como la sociedad genera en tales ocasiones. La notable bibliografía que sobre divorcios en los siglos XVII y XVIII se ha ido reuniendo para el territorio peninsular desde los años 80 , incluida alguna obra que ofrece un panorama general ${ }^{145}$, me exime de un estado de la cuestión detenido que no haría sino redundar en aspectos sobradamente conocidos. Los expedientes de separación matrimonial, mal llamados divorcios, frecuentes en los Provisoratos, constituyen una prueba fehaciente del peso que en la conformación de la identidad masculina tenía la convicción del poder de corrección de los maridos sobre sus mujeres y la cotidianeidad de un conjunto de prácticas de violencia, simbólica y física, que se

140. GIL, A.: Historia de la violencia contra las mujeres. Misoginia y conflicto matrimonial en España. Madrid, 2008, p. 207.

141. Idem, p. 207.

142. CAMPO, J.: «Los procesos por causa matrimonial ante el tribunal eclesiástico de Pamplona. Siglos XVI y XVII», Príncipe de Viana, 202, 1994, pp. 377-389.

143. Morgado, A.: «El divorcio en el Cádiz del siglo XviII», Trocadero, 6-7, 1994-95, pp. $125-135$.

144. GIL, A.: Historia de la violencia, op. cit., pp. 208-210.

145. Ibidem.

(C) Ediciones Universidad de Salamanca / ®®@ Stud. his., H. ${ }^{a}$ mod., 38, n. 2 (2016), pp. 237-285 
MARÍA JOSÉ DE LA PASCUA SÁNCHEZ

«A LA SOMBRA» DE HOMBRES AUSENTES:

MUJERES MALCASADAS EN EL MUNDO HISPÁNICO DEL SETECIENTOS

ejercía de forma arbitraria. Esta era, al menos, la queja de las mujeres que, educadas asimismo en esos principios, no osaban declarar ante el juez nada en contra del derecho de sus maridos a corregirlas, sino de la gratuidad y la sinrazón con la que esta violencia era ejercida. Esta situación refleja una cultura de «normalización» de la corrección marital tolerada socialmente y presente entre tratadistas y moralistas que se esforzaban por casar dos realidades imposibles: el castigo moderado realizado con el propósito de conseguir la enmienda y el respeto a la institución matrimonial como lugar de armonía. Ellas vertían acusaciones sobre violencias ejercidas injustamente por sus maridos ${ }^{146}$, pero ellos también comparecían bien pertrechados de argumentos cuando respondían al juez y acusaban a su esposa de genio indómito o falta de respeto ${ }^{147}$.

En el caso de la demanda de divorcio, una vez que se formalizaba esta, el primer paso era la extracción de la mujer de la vivienda familiar y su depósito en sitio seguro; luego el juez solicitaba a las partes información y testimonios para, cuando lo considerara suficiente, dictar sentencia. El proceso estaba plagado de inconvenientes para las mujeres que, desde un primer momento, debían abandonar su hogar y quedar a merced de parientes o de la caridad de terceros. Aunque muchos de estos tribunales dictaminan sobre los bienes del matrimonio adjudicando a la mujer una pensión alimenticia o la devolución de sus bienes, no tenían medios para hacerlo cumplir salvo la amenaza de excomunión. En estas condiciones no era extraño que los intentos de mediación por «personas de autoridad» condujesen a la reunión de la pareja o que esta se eternizase en una situación insostenible de enfrentamiento continuo, que generaba demandas de auxilio por parte de la esposa en forma de su derecho a parte de sus bienes o la necesidad de una orden de alejamiento para su marido. Aun así, la demanda de divorcio no era más que uno de los últimos pasos que podía darse en una situación de violencia doméstica y que, en muchas ocasiones, no podía materializarse por la negativa o la ausencia

146. En las causas tramitadas en el obispado de Barcelona entre 1565 y 1650, de malos tratos (122 casos), amenazas de muerte (51 casos), intentos de asesinato (26), falta de manutención (26), abandono y dispendio de bienes (25), adulterio y concubinato (15), un marido borracho, jugador o loco furioso (13), que la expulsa de casa (6)), la incita al adulterio (1), o la carga de trabajo excesivo (1), según la relación de motivos de 152 demandas de divorcio, masivamente iniciadas por mujeres, GIL, A.: El matrimonio catalán entre 1565 y 1650: régimen jurídico y fracaso conyugal en la diócesis de Barcelona. Tesina de Licenciatura, Universidad Autónoma de Barcelona, 1984, pp. 30-35.

147. Testimonios de unas cien sumaria con historias de adulterio, malos tratos y abandono de los años 1662-1795, CANDAU, M. ${ }^{a}$ L.: «La Mujer, el matrimonio y la justicia eclesiástica. Adulterio y malos tratos en la archidiócesis hispalense. Siglos XVII y XVIII», en Actas del III Congreso de Historia de Andalucía. La Mujer. Córdoba, Caja de Ahorros de Córdoba, 2002, 219-230, pp. 226-227.

(C) Ediciones Universidad de Salamanca / ®@ Stud. his., H. ${ }^{a}$ mod., 38, n. 2 (2016), pp. 237-285 
MARÍA JOSÉ DE LA PASCUA SÁNCHEZ

«A LA SOMBRA» DE HOMBRES AUSENTES:

MUJERES MALCASADAS EN EL MUNDO HISPÁNICO DEL SETECIENTOS

del marido. La demanda por malos tratos que interpone Josefa Guerrero ante el juez eclesiástico del obispado de Cádiz, en 1736, es significativa de las situaciones por las que pasaban estas mujeres y del «final» inconcluso de algunas de estas demandas. Los padres de Josefa Guerrero habían acudido a la Curia de Cádiz a denunciar los malos tratos «de palabra y de obra» que su hija sufría por parte de su marido, Bartolomé Olar. El provisor había citado a la pareja a declarar y después había "apercibido» al marido; pero la llamada de atención no solo no había servido para nada, sino que tras ella el marido había intentado ahogarla ${ }^{148}$. La huida protagonizada por la esposa, aunque dio paso a la separación de los cónyuges con la orden de depósito de Josefa en casa de sus padres, no evitó que las amenazas siguieran pues el marido «rondaba la puerta de noche en compañía de otros hombres» -incluso de alguno que iba armado-. Josefa solicitará lo que conocemos como una orden de alejamiento; también que se le devuelva su ropa, abandonada en su marcha precipitada y declara que está decidida a cursar una demanda de divorcio y a pedir la pensión que le corresponde ${ }^{149}$. A finales de diciembre, Josefa se presenta ante el provisor con una nueva petición: esta vez da cuenta de que su marido ha huido a Ceuta llevándose sus bienes y quiere que se le aprese. La requisitoria se despacha y un mes más tarde se le informa de que las diligencias realizadas en Ceuta no han dado resultado, puesto que su marido ya no se encontraba en aquella ciudad, sino que se había embarcado para Italia ${ }^{150}$. En este caso, a diferencia de lo que ocurre con otros, todo había transcurrido con celeridad: se habían casado en Cádiz a mediados de octubre de 1736, dos meses de violencia y de un intento de asesinato y de las correspondientes demandas llevan a esta mujer de vuelta al hogar de sus padres, sin ropa, sin bienes y en un estado civil incierto.

La demanda de divorcio que Luisa de la Torre había interpuesto, incapaz de seguir soportando los malos tratos de su marido ${ }^{151}$, tampoco había prosperado al huir este y dejar el pleito pendiente. Luisa reclamará a la justicia, quince años después, en 1751, el regreso forzoso de su marido para continuar el divorcio y el embargo de sus bienes para pagar todos los años de pensión que le adeuda ${ }^{152}$.

148. ADC, Varios, libro 1854, año 1736.

149. Ibidem.

150. Ibidem.

151. Como en otros casos antes de llegar a la demanda de separación legal se habían arbitrado varias soluciones de compromiso y todo tipo de «apercibimientos, reconvenciones, lágrimas y ruegos», pero de nada habían servido, tampoco la intervención del hermano de su marido, a la sazón alguacil mayor del tribunal eclesiástico, en PASCUA, M. ${ }^{a}$ J. de la: Mujeres solas, op. cit., pp. 316-318.

152. Ibidem.

(C) Ediciones Universidad de Salamanca / ®®@ Stud. his., H. ${ }^{a}$ mod., 38, n. 2 (2016), pp. 237-285 
En esta ocasión, la relevancia social de la familia había potenciado el efecto de «escándalo» con el que la comunidad recibía noticias como estas, aunque en otras ocasiones el apoyo de una familia socialmente destacada surte efecto y estas mujeres hallan solución relativamente pronta a sus problemas.

Más allá de los datos cuantitativos que sobre divorcios y separaciones se obtienen básicamente de los tribunales eclesiásticos, estudios de caso a partir de los relatos de vida proporcionan nuevas posibilidades de enfoque y, concretamente, sortear la perspectiva roma y marcadamente victimista con la que habitualmente se enfoca el tema y que deriva, en parte, de la carencia, en muchas ocasiones, de la sentencia dictada. Respecto a la resolución de los pleitos parece imponerse la percepción de una cierta indecisión -desidia, tal vez-, en el tratamiento del tema, en parte por la trascendencia social de una ruptura oficializada de la relación de convivencia, en parte también por el recurso habitual en la época a la composición entre partes. En esta vía de tratamiento del conflicto triunfa un modo de interpretar la ley que concibe el arbitraje y la intervención de los poderes judiciales, basándose no tanto en la idea de castigo, como en la de restaurar la paz. Así, las causas judiciales de separación se alargaban y la solución se componía en el día a día, salvo en algunos casos donde la gravedad de la situación y/o la intervención de parientes poderosos e influyentes daba celeridad a la resolución definitiva del proceso. En ese sentido, el análisis detenido de algunos de esos pleitos de separación y de nulidad matrimonial, ofrece claves que no pueden ser subestimadas. Uno de ellos es el divorcio de Teresa Leal de Barrios estudiado por mí en otro lugar ${ }^{153}$, por lo que no entraré en detalles sobre el mismo; un divorcio que sustanciado por vía sumaria, cuenta con sentencia definitiva, con acuerdo sobre los bienes, en cuatro meses. Es destacable, en este caso, en la rapidez de todo el proceso y en el tenor de la solución, la actuación de las dos abuelas de la familia pertenecientes a una familia destacada de comerciantes de Indias del Cádiz finisesentista. Este es el caso también, aunque con un proceso mucho más dilatado, de otra mujer malcasada ${ }^{154}$, para quien el apoyo de su familia fue, asimismo, importante, pero que, a diferencia de la anterior, será ella misma la que lleve la iniciativa y señale los tiempos, al menos en la primera etapa de su separación. A pesar de su edad, en la sesentena, se empeñará, primero en el divorcio y luego en una demanda de restitución de sus bienes. Sebastiana de Torres y Manuel del Corro habían sido protagonistas, en 1741, de uno de esos matrimonios secretos, concertados sin amonestaciones

153. Idem, pp. 325-335.

154. Pascua, M. J. de la: «Violencia y familia en la España Moderna», en Castellano, J. L., López-Guadalupe, M. L. (Eds.): Actas de la XI Reunión Científica de la Fundación Española de historia Moderna. Granada, 2012, pp. 127-157.

(C) Ediciones Universidad de Salamanca / ®@ Stud. his., H. ${ }^{a}$ mod., 38, n. 2 (2016), pp. 237-285 
MARÍA JOSÉ DE LA PASCUA SÁNCHEZ

«A LA SOMBRA» DE HOMBRES AUSENTES:

MUJERES MALCASADAS EN EL MUNDO HISPÁNICO DEL SETECIENTOS

públicas y con licencia del Provisor porque intervenía alguna circunstancia que lo aconsejaba. Así era en esta ocasión, ya que la familia de la novia se mostraba en desacuerdo con un enlace en el que la diferencia de edad entre los contrayentes era notable. Manuel, el novio, contaba con 20 años en el momento de contraer matrimonio, mientras que ella, Sebastiana, tenía 53. El acababa de llegar a Cádiz, como muchos otros, apenas tres años antes para labrarse un porvenir y carecía de bienes. Ella, en cambio, aportaba al matrimonio una dote de más de 182.500 reales ${ }^{155}$. Él parece estar sin familia -no hay datos en este sentido a lo largo del proceso-, ella, aunque la tiene en las personas de sus hermanos, puesto que sus padres han fallecido, rompe con ella para casarse. En abril 1751, después de diez años de matrimonio y, según ella, de tres o cuatro de sufrir malos tratos de todo tipo, interpone demanda de divorcio ${ }^{156}$, aprovechando la ausencia de su marido en El Puerto de Santa María. Informado el juez de la curia gaditana, Sebastiana es depositada en casa del alguacil mayor del tribunal eclesiástico, colocándose frente a las casas del matrimonio una guardia para impedir la entrada en ellas del marido. Durante el matrimonio, declarará ella en uno de sus últimos testamentos, su marido había manejado el caudal de ella, como si fuera propio y además con poca fortuna. No debía ser este el motivo principal de su decisión, pero probablemente tampoco era un tema baladí, teniendo en cuenta que cuando comenta estas circunstancias, años después, cuando el pleito de divorcio se ha sustanciado ya y tiene 70 años, Sebastiana aún mantiene cierta actividad comercial ${ }^{157}$ y ha recuperado con el control sobre su vida el de sus bienes. Vive con su hermano, Miguel de Torres y su cuñada y se confiesa confiada de sus cuidados y su «fraternal amor» ${ }^{158}$, reconciliada con él después que le diera todo su apoyo con motivo de su demanda de divorcio. Esta, según puede deducirse del amplio expediente que genera, había sido decidida oportunamente por Sebastiana, que contó a su confesor que recibía malos tratos y le pidió que se lo hiciera saber a su familia. Interpuesta la demanda, cuando el marido, avisado de lo que acontecía, regresó, se halló, según declaración propia, ante el hecho «inusitado», de verse despojado de su casa, bienes y hasta de su ropa «cosa irregular, no experimentada -hasta entonces- en términos judiciales» ${ }^{159}$. El discurso de ambos cónyuges permanecerá invariable

155. AHPC, Protocolos, libro 1319, año 1754-55, fols. 78-82.

156. «le ha dado tan mala vida y maltrato, castigándola con golpes y amenazándola con armas para tenerla oprimida», ADC, Varios, leg. 288, año 1741, fols. 15 y 15v.

157. AHPC, Protocolos, libro 1320, año 1756, fols. 203-204.

158. AHPC, Protocolos, libro 1320, año 1756, fols. 86-90.

159. «Con notable perjuicio en su estimación, crédito y reputación [...], desalojo de su casa, el bochorno de los guardias y la interdicción en el manejo de sus bienes y el uso de las facultades que por derecho tiene...», ADC, Varios, leg. 305, fols. 3-7.

(C) Ediciones Universidad de Salamanca / ®®@ Stud. his., H. ${ }^{a}$ mod., 38, n. 2 (2016), pp. 237-285 
en declaraciones y apelaciones. Para él, su mujer estaba bajo la influencia de su familia, que nunca había estado de acuerdo con el enlace y si se la interrogaba en libertad consentiría en volver con él; el otro argumento que repite versa sobre lo inapropiado y extremo de las medidas preventivas contra él tomadas por el Provisor ${ }^{160}$. Según Manuel del Corro, aunque fuese verdad que habían existido malos tratos, no estaban justificadas y se había procedido «en contra de toda razón de justicia y equidad», «dando que hablar en el pueblo», cuando debía empeñarse en todo lo contrario. Tres días después de que comenzaran las diligencias ante la audiencia episcopal, tras la reiterada petición de Sebastiana de Torres, se ordena ejecutar el inventario ${ }^{161}$. Se procede a dar noticia de lo encontrado en la casa, primero en las habitaciones de Manuel y después en las de Sebastiana. Cuando se pormenoriza la naturaleza de los papeles encontrados vemos los testimonios de la actividad económica de la pareja, conjunta y en solitario y de los bienes y derechos de cada uno, pero lo que Sebastiana quería encontrar entre los papeles privados de su marido eran los testimonios de su infidelidad y se encontraron. En una papelera se hallaron «setenta y siete cartas amatorias escritas» por alguien que firmaba «tu hermana Theresa» así como el certificado de bautismo de una niña, una hija ilegítima, que Manuel del Corro había expuesto en la Cuna y después había dado a criar a un ama ${ }^{162}$.

En estas condiciones, las estrategias de la pareja de cara a la solución de su conflicto están claramente definidas: ella, decidida al divorcio, se ocupa en poner a salvo su caudal, escribir cartas a comerciantes para salvaguardar el producto de sus ventas, aclarar correspondientes que su marido no tiene y a la administración de las mismas y recuperar facturas de mercancías que aquel había camuflado bajo nombres falsos. Mientras él, preocupado porque en la curia gaditana no se oyen sus apelaciones y Sebastiana no cede a la petición de careo, recurre al metropolitano de Sevilla y hace presente sus argumentos, básicamente, las extorsiones injustificadas y excesivas que ha padecido en el tribunal de Cádiz. A finales del mes en el que se interpuso la demanda, ante la inhibición obligada del diocesano de Cádiz, Sebastiana reitera su petición y argumentos en la curia arzobispal de Sevilla y a la petición de divorcio, añade la demanda de devolución de la dote que fija en 23.000 pesos. Aunque en el expediente no consta la sentencia de divorcio, sí la conocemos por el último testamento que

160. «pues aún en el más adverso acontecimiento de que se le hubiera podido justificar que [...] la había tratado con la mayor sevicia, no podía haber méritos en el legal concepto para una extorsión de tanta nota», Idem, fol. 30.

161. Ibidem.

162. Idem, fols. $21 \mathrm{v}-23 \mathrm{r}$. 
MARÍA JOSÉ DE LA PASCUA SÁNCHEZ

«A LA SOMBRA» DE HOMBRES AUSENTES:

MUJERES MALCASADAS EN EL MUNDO HISPÁNICO DEL SETECIENTOS

Sebastiana de Torres otorga, en 1756 y bajo cuya disposición muere dos años después, cuando cuenta con 73 años. Por entonces, el divorcio era firme, aunque continuaba el pleito por la devolución de la dote.

Sin embargo, lo que me parece más interesante del expediente es aquello que permite comprender parte de la violencia marital: la sorpresa de un marido porque se cuestionan sus derechos «absolutos» en el matrimonio y que no se le permita volver a su casa y al manejo de sus bienes. Habla de sus bienes, de su casa, de su reputación: ni por un momento parece ser consciente que los bienes pertenecían a su esposa, que él los había administrado mal y que esta había decidido acabar con una vida matrimonial en la que él faltaba a sus deberes y obligaciones. Tan seguro se hallaba de sus derechos incuestionables como marido que se presenta como víctima ${ }^{163}$, versión complementaria de aquella otra amenazante que declaraba el marido de Teresa Leal a la abuela de esta, cuando se negociaba el nuevo statu $q u o^{164}$. En el caso de Manuel del Corro, tenía enfrente no sólo a una esposa con apoyos familiares y afectivos, sino también una mujer que no estaba dispuesta a ceder más.

Lo dilatado de la mayoría de estos procesos de divorcio, que permanecían sin sentencia firme durante largos años, unido a la medida cautelar de depósito de la esposa en la casa de algún familiar o en un convento, convertían este periodo de espera para las mujeres en una larga agonía. Así sucede para Isabel Fauria, esposa de Pablo de Guseme, Vista de la Real Aduana de Cádiz, depositada en el convento de religiosas de Santa María desde que interpone demanda de divorcio y que, con el apoyo de una certificación médica, solicita al tribunal su salida del convento para poder curarse. En el argumentario de su petición expone lo dilatado de su encierro, sus frustradas esperanzas de que el litigio acabe para poder salir de la clausura, así como el temor de que por la «duración negligente» del mismo llegue antes su muerte que el final del pleito» ${ }^{165}$. Su marido, cuya intención era que ella permaneciese sine die enclaustrada, propone, ante la petición de su esposa, un nuevo diagnóstico por una nueva junta de médicos ${ }^{166}$, esta vez elegida por él. En

163. «Atento a no haberse hasta ahora experimentado caso igual, de lanzarse a un marido de su casa porque su mujer, con razón o sin ella, intente o le haya puesto una demanda de divorcio», Ibidem, fol. 17.

164. "Y vuelvo a encargar a vuestra merced el secreto, porque soy hombre y me recelo de mi natural y si Dios me deja de su mano no me he de poder vencer para matar a mi mujer», Pascua, M. J. de la: Mujeres Solas, op. cit., p. 331.

165. ADC, Divorcios, libro 1067 II, años 1796-1801.

166. El diagnóstico de estos incide en que la citada enfermedad ni es aguda, ni crónica ni va acompañada de peligro de vida y que, muchas veces, se hace habitual sin riesgo evidente en el sexo femenino, Ibidem.

(C) Ediciones Universidad de Salamanca / ®®@ Stud. his., H. ${ }^{a}$ mod., 38, n. 2 (2016), pp. 237-285 
su opinión, su esposa «pinta» su enfermedad de «muy vivos colores» y sospecha que lo único que quiere es salir de la clausura. Esta, según razona, es necesaria para evitar el escándalo y la merma que se ha originado en su estimación pública y la ruina de su casa e intereses, y porque la solicitud de su mujer responde al propósito de vengarse de él, sin otra causa que los intentos suyos de corregir los excesos y el carácter de su esposa. El fundamento del alegato del marido es que todo esto de la enfermedad no es más que un pretexto para salir libre, algo que no puede consentirse sin vulnerar el espíritu de las leyes y el derecho de un marido «altamente agraviado» con una demanda que ha manchado su crédito público y ha violado la dependencia que la religión, la naturaleza y la sociedad imponen a las mujeres casadas ${ }^{167}$. La conclusión de su alegato es todo un discurso sobre el derecho de corrección de los maridos sobre sus mujeres ${ }^{168}$, al tiempo que desvela su propósito más directo: la vindicación pública de su agravio y lo injustificado de la petición de divorcio que solo nace del «desorden de las ideas» de su mujer ${ }^{169}$. Este marido exigía un resarcimiento público, el mismo que trataba de frustrar su esposa, según él, por medio indirecto a través de una petición de exclaustración. Y porque «su honor, los respetables derechos de marido, la tranquilidad parcial de la sociedad, exigen la retención de mi consorte en el depósito», conviene se deniegue dicha petición ${ }^{170}$. Las referencias generales sobre el caos social que generaría el no castigo de tales «excesos», tampoco falta en esta encendida vindicación de los derechos maritales:

En efecto, el cuerpo social en su régimen económico y doméstico, estaría expuesto a continuas perturbaciones si las mujeres casadas lograsen desprenderse de la dependencia natural y civil de sus maridos, a la sombra de unas demandas que ofenden el pudor y que manifiestan intolerancia a la sujeción de aquellas obligaciones que hacen meritorio el estado del matrimonio ${ }^{171}$.

167. Idem, fol. 22.

168. «En conclusión: mi honor, los respetables derechos de marido y la tranquilidad parcial de la sociedad exigen la retención de mi consorte en el depósito» (...) en respuesta a «una demanda calumniosa, altamente ofensiva de mi crédito público y los derechos naturales y civiles que autorizan a un marido para que su consorte observe aquella subordinación moral y política que impone la Naturaleza y la Ley», Idem, fol. 23v.

169. «La causa está abierta y [...] no abandonaré el ejercicio de aquellos medios que me pongan en estado de solicitar mi desagravio y la imposición de las correcciones a que den lugar los hechos en que apoyaré mi defensa, pues es repugnante a toda consideración legal que un marido honrado se vea acometido por la propia consorte en lo más vivo del honor y que semejante atentado subsista impune», Idem, fol. 24.

170. Idem, fol. 24.

171. Idem, fol. $22 \mathrm{v}$. 
MARÍA JOSÉ DE LA PASCUA SÁNCHEZ

«A LA SOMBRA» DE HOMBRES AUSENTES:

MUJERES MALCASADAS EN EL MUNDO HISPÁNICO DEL SETECIENTOS

Concepción, por otra parte, no discutida. En la respuesta a este alegato, el procurador de su esposa, después de precisar que no se trata aquí ni del divorcio ni de sus causas, alega que es solo una cuestión de salud y que su parte no pretende que se la deje «en espontánea libertad» ${ }^{172}$.

Adulterios y malos tratos eran quejas frecuentes en boca de las mujeres que demandaban un divorcio. Muchos hombres interpretaban estas demandas, de acuerdo con su concepción del matrimonio y los deberes de las esposas, como una desobediencia y una falta de respeto a su autoridad como marido. Los resultados de estas situaciones generaban, en ocasiones, mayores violencias y el intento o muerte de las propias mujeres. Las cifras, en el rastreo de la violencia de género, la mayoría de las veces no proporcionan sino datos muy parciales ${ }^{173}$. En el inventario de sumarios estudiados por mí no se encuentra, por ejemplo, el intento de homicidio Diego Barrios de la Rosa sobre su esposa Teresa Leal ya mencionado y localizado por otras fuentes, ni tampoco el asesinato de Catalina Barba a manos de su esposo Juan Hurtado de Chaves, conde de Cartago, en 1698, que también conocemos a través de otros documentos ${ }^{174}$. Juan Hurtado de Chaves había nacido en Lima, segundo hijo de José Hurtado de Chaves, primer conde de Cartago. Allí había dado palabra de matrimonio a una joven libre y soltera, honrada y de ilustre sangre, con la que había tenido dos hijos y a la que había abandonado cuando se hallaba embarazada de un tercero. Se había ausentado de Lima, peregrinando por diversas cortes -la de México, la de Madrid- y ciudades, frecuentando en ellas garitos y casas de juego -en todas ellas dejaba acreedores según su disposición testamentaria-. Finalmente se establece en Cádiz, donde contrae matrimonio con una joven viuda, Catalina Barba en 1693. Él no había llevado bienes al matrimonio, puesto que sus legítimas paterna y materna las había «disipado» y ella aportó el oficio de guardia mayor de la avería, heredado de su anterior marido. Un tío de ella, presbítero, había dotado a Catalina con 600 pesos y con el dinero necesario para los primeros gastos. De los cinco años que estarán casados hasta que ella pide el divorcio y él la mata solo sabemos que él había intentado hacerse un hueco en el comercio sin lograrlo y que le daba mala vida a causa de unos «celos fantásticos». Cuando parecía que sus problemas económicos se solucionaban porque a la muerte de su hermano le correspondía ser el titular del mayorazgo -con una

172. «A mi que el derecho no prescribe la necesidad de que los depósitos, en caso de divorcio, hayan de establecerse en conventos», Idem, fols. $29 \mathrm{v}-30$.

173. Un inventario de 3.385 causas que pasan ante una escribanía gaditana entre 1596 y 1773 contiene los rastros de la violencia familiar junto a 9 causas por agresión física de maridos a sus esposas y 3 tentativas más de asesinato, PASCUA, M. J. de la: «Violencia y familia», op. cit.

174. Pascua, M. J. de la: Mujeres Solas, op. cit., pp. 336-342.

(C) Ediciones Universidad de Salamanca / ®®@ Stud. his., H. ${ }^{a}$ mod., 38, n. 2 (2016), pp. 237-285 
renta anual de de 8.000 pesos-, su esposa interpuso la demanda de divorcio y él la mató ${ }^{175}$. En sus últimas declaraciones -testamento y romance de un pecador arrepentido, ambos del año 1699 y este último publicado en Cádiz bajo el título Afectos amorosos ${ }^{176}$ - además de la petición de perdón, el conde de Cartago ofrece su interpretación sobre lo ocurrido, culpando de la muerte de su esposa a los celos y al amor que sentía por ella. Ese tipo de amor-pasión que, a su juicio, él había incorporado a otras tantas transgresiones a su estado (abandono de su prometida de familia noble y de los hijos habidos con ella, derroche irresponsable de sus bienes y celebración de un matrimonio desigual). El conde de Cartago interpretaba su «desgracia» como si del argumento de una novela sentimental barroca se tratase, donde los comportamientos que transgreden la identidad social de cada uno desencadenan todo tipo de males. Solo que en este esquema de «buena muerte» que asume el conde de Cartago, apoyado sobre un arrepentimiento público, el pecador consigue torcer, en un último instante, un mal destino eterno. Parecido esquema de arrepentimiento, aunque mucho más discreto, acompaña al cadalso a María del Rosario Báez, acusada de homicidio reincidente por haber dado muerte a sus dos hijos pequeños. El relato sobre su ejecución -la única mujer ejecutada en Cádiz entre las 133 personas que lo son entre 1758 y 1909- se detiene más en la preparación de su muerte, su conducción ejemplar al cadalso y sus oraciones de arrepentimiento que en las circunstancias de su doble crimen. Solo sabemos que era una de esas esposas abandonadas por un marido ausente en Indias, que había llevado una vida «licenciosa», que había estado en la cárcel condenada por dar muerte a un hijo y que, cuando salió de la cárcel, había continuado con su comportamiento «desviado» matando a un segundo hijo ${ }^{177}$. Su infortunio permite completar este círculo de abandonos, rupturas y violencias entre la pareja desde la perspectiva de las mujeres solas con una llamada de atención sobre la complejidad de sus itinerarios vitales.

175. Idem, pp. 336-342.

176. Afectos amorosos que en un acto de verdadera contrición ofreció a Christo Señor Nuestro, despidiéndose de esta miserable vida, don Juan Hurtado de Chaves y Quesada En Cádiz, Imprenta de Cristóbal de Requena, [1699]. Biblioteca Nacional de Madrid. Raros Especiales, 137-19. Idem, pp. 336-342.

177. PASCUA, M. J. de la: «Regulación de transgresiones y rituales de penalización en el contexto normativo de una sociedad de Antiguo Régimen», en GoNZÁLEZ, D. (Ed.): Ritos y ceremonias en el Mundo Hispano durante la edad moderna. Huelva, 2002, pp. 199-208.

(C) Ediciones Universidad de Salamanca / ®@ Stud. his., H. ${ }^{a}$ mod., 38, n. 2 (2016), pp. 237-285 
MARÍA JOSÉ DE LA PASCUA SÁNCHEZ

«A LA SOMBRA» DE HOMBRES AUSENTES:

MUJERES MALCASADAS EN EL MUNDO HISPÁNICO DEL SETECIENTOS

\section{BibliografíA}

Alexander, R.: «Women's Work in Nineteenth-Century London: A Study of the Years 1820-50», en Mitchell, J. OAKley, A. (Eds.): Rights and Wrongs of Women. Harmondsworth, Penguin, 1976.

Arias de SaAvedra, I., López-Guadalupe, M. L.: «Asistencia sanitaria femenina a finales del Antiguo Régimen: el caso del Hospital de la Caridad y Refugio de Granada», Cuadernos de Historia Moderna, 2015, XIV, 33-61.

Bennett, J. M., Froide, A. M. (Eds.): Single Women in European Past, 1250-1800. Filadelfia, University of Pennsylvania Press, 1999.

Berg, M.: La era de las manufacturas, 1700-1820. Una nueva historia de la Revolución industrial británica. Barcelona, Crítica, 1987.

Berteaux, D.: Le récit de vie. París, Armand Colin, 2006.

Birriel, M. M.. : «Jefaturas de hogar femeninas en la ciudad de Granada (1752), I: Caracterización demográfica del hogar», en Cortés, A. L., López-Guadalupe, M. L., SÁnCHEZ-MonTes, F. (Eds.): Estudios en Homenaje al profesor José Szmolka Clares. Granada, Universidad de Granada, 2005, pp. 591-604.

Bourdieu, P.: «L'illusion biographique », Actes de la recherche en Sciences Sociales, 1986, vol. 62, n. 62-63, pp. 69-72.

CAmpo, J.: «Los procesos por causa matrimonial ante el tribunal eclesiástico de Pamplona. Siglos XVI y XVII», Príncipe de Viana, 202, 1994, pp. 377-389.

CAmps, E.: «Las migraciones locales en España, siglos XVI-XIX», Boletín de la ADEH, XI, 1, 1993, pp. 26-30.

CANDAU, M. ${ }^{a}$ L: «La Mujer, el matrimonio y la justicia eclesiástica. Adulterio y malos tratos en la archidiócesis hispalense. Siglos XVII y XVIII», en Actas del III Congreso de Historia de Andalucía. La Mujer. Córdoba, Caja de Ahorros de Córdoba, 2002, 219-230.

Carbonell, M.: «Les dones pobres a la Barcelona del segle XVIII », Historia social, 8, 1990, 123-135.

Carbonell, M.: «Fuentes para la Historia de las Mujeres en los archivos asistenciales, siglos XVI-XVIII)», en BIRRIEL, M. (Ed.): Nuevas preguntas, nuevas miradas. Fuentes y documentación para la historia de las mujeres (siglos XVI-XVIII). Granada, Universidad de Granada, 1992, pp. 59-78.

Carbonell, M.: «Trabajo femenino y economías familiares», en Morant, I. (Dir.): Historia de las mujeres en España y América Latina. Vol. II. Madrid, Cátedra, 2005, pp. 237-262.

Carmona, J. I.: Mercado inmobiliario, población, realidad social. Sevilla en los tiempos de la Edad Moderna. Sevilla, Universidad de Sevilla, 2015.

Clark, A.: Working Life of Women in the Seventeenth Century. Londres, G. Routledge \& Songs, 1919.

Davis, N. Z.: «Las formas de la Historia Social», Historia Social, 10, primavera-verano 1991, pp. 177-182, p. 179.

DAvis, N. Z.: Sociedad y cultura en la Francia moderna. Barcelona, Crítica, 1993.

(C) Ediciones Universidad de Salamanca / ®@ Stud. his., H. ${ }^{a}$ mod., 38, n. 2 (2016), pp. 237-285 


\section{MARÍA JOSÉ DE LA PASCUA SÁNCHEZ \\ «A LA SOMBRA» DE HOMBRES AUSENTES: \\ MUJERES MALCASADAS EN EL MUNDO HISPÁNICO DEL SETECIENTOS}

Dedieu, J. P.: «Estructura de la actividad procesal del Santo Oficio», en Historia de la Inquisición en España y América, t. II. Madrid, Biblioteca de Autores Cristianos, 1984, pp. 629-632.

Fernández, A.: «La Casa de recogidas de Cuenca (1776-1845): desobediencia, delitos y penas de las mujeres entre la Ilustración y el Romanticismo», en PAscuA, M.a J. de la, Espigado, G. (Eds.): Frasquita Larrea y Aberán. Europeas y españolas entre la Ilustración y el Romanticismo, 1750-1850. Cádiz, Universidad de Cádiz, 2003, pp. 297-323.

Figueras, E.: Pervirtiendo el orden del matrimonio. Bígamas en México, siglos XVI-XVII. Barcelona, Publicaciones de la Universidad de Barcelona, 2003.

GACTO, E.: «El delito de bigamia y la Inquisición española», en Sexo Barroco y otras transgresiones premodernas. Madrid, Alianza editorial, 1990, pp. 127-152.

García-AbÁsolo, A.: La vida y la muerte en Indias. Cordobeses en América (siglos XVI-XVIII). Córdoba, Caja de Ahorros de Córdoba, 1992.

GARCíA, F.: «Mujer, hogar y economía familiar. Desigualdad y adaptación en la Sierra de Alcaraz a mediados del siglo XVIII», Hispania LVII (1), 195, 1997, 115-145.

GARCíA, F.: «Investigar la soledad. Mujeres solas, casa y trayectorias sociales en la Castilla rural a finales del Antiguo Régimen», Obradoiro de Historia Moderna, 24, 2015, pp. 141-169.

GIL, A.: El matrimonio catalán entre 1565 y 1650: régimen jurídico y fracaso conyugal en la diócesis de Barcelona. Tesis de Licenciatura, Universidad Autónoma de Barcelona, 1984.

GIL, A.: Historia de la violencia contra las mujeres. Misoginia y conflicto matrimonial en España. Madrid, 2008.

Gurevich, A.: Los orígenes del individualismo europeo. Barcelona, Crítica, 1997.

Hartmann, H.: «Capitalism, Patriarchy and Job Segregation by Sex», Sings 1, 9, 1976, pp. 137169.

Hartmann, H.: «The Family as the Locus of Gender, Class and Political Struggle: the Example of Housework», Sings, 6, 3, 1981, pp. 366-394.

HaRTMANN, H.: «La emigración americana y su influencia sobre la vida conyugal en Canarias durante el siglo XVIII», Anuario de Estudios Atlánticos, 36, 1990, pp. 353-377.

Hourcade, J. M.: «Asistidas, recogidas, corregidas: el lugar de la mujer en el sistema asistencial del siglo XVIII», en Congreso Internacional de Historia de la Familia: Nuevas perspectivas sobre la sociedad europea (Murcia, 1994). Murcia, Universidad de Murcia, 1997, pp. 233-240.

Kriedte, P., Medick, H., Schlumbohm, J.: Industrialización antes de la Industrialización. Barcelona. Crítica, 1976.

LANZA, R.: «De norte a sur: las migraciones de la fachada cantábrica en la España Moderna», en EIras, A., GonzÁlez, D. (Coord.): Movilidad interna y migraciones intraeuropeas en la Peninsula Ibérica. Actas del Coloquio Europeo sobre Migraciones. Santiago de Compostela, Universidad de Santiago de Compostela, 2002, pp. 17-53.

(C) Ediciones Universidad de Salamanca / @@ Stud. his., H. ${ }^{a}$ mod., 38, n. 2 (2016), pp. 237-285 
MARÍA JOSÉ DE LA PASCUA SÁNCHEZ

«A LA SOMBRA» DE HOMBRES AUSENTES:

MUJERES MALCASADAS EN EL MUNDO HISPÁNICO DEL SETECIENTOS

Liddington, J., Norris, J.: One Hand Tied Behind Us: The Rise of the Women's Suffrage Movement. Londres, Virago, 1978.

Martín, J. F., DíAz, M. ${ }^{a}$ C.: «La natalidad ilegítima en la formación social canaria: las repercusiones de la emigración americana», V Coloquio de Historia Canario-Americana, t. I., 1985, pp. 205-218.

Matrician, M: «Women's Legal Conflicts in Fifteenth Century Germany», Women, Family, Private Life and Sexuality, Conference of the International Federation for Research in Women's History. Paper Abstracts. Belfast, Queen's University, 2003.

Mendelson, S. H., Crawford, P.: Women in Early Modern England, 1550-1720. Oxford, Clarendon Press, 1998.

Morgado, A.: «El divorcio en el Cádiz del siglo XviII», Trocadero, 6-7, 1994-95, pp. 125-135.

Palazzi, M.: «Female Solitude and Patrilineage: Unmarried Women and Widows during the Eighteenth and Nineteenth Centuries», Journal of Family History, 4, vol. 15, pp. 443-459.

Pascua, M. ${ }^{a}$ J. de la: «La fundación de la Casa de las Viudas: el gesto ilustrado de un comerciante de Damasco», en La burguesía de negocios en la Andalucía de la Ilustración. Cádiz, Diputación Provincial, 1991, pp. 283-297.

PAscua, M. J. de la: «Pobreza y asistencia social en el Jerez del siglo XVIII, en IV Jornadas de Historia de Jerez. Jerez, Biblioteca de Urbanismo y Cultura, 1992, pp. 33-44.

PAscua, M. J J. de la: «La cara oculta del sueño indiano: mujeres abandonadas en el Cádiz de la Carrera de Indias», Chronica Nova, 21, 1993-1994, pp. 441-468.

Pascua, M. J. de la: Mujeres Solas: historias de amor y de abandono en el mundo hispánico. Málaga, CEDMA, 1998.

Pascua, M. J J. de la: «Regulación de transgresiones y rituales de penalización en el contexto normativo de una sociedad de Antiguo Régimen», GonzÁlez, D. (ed.): Ritos y ceremonias en el Mundo Hispano durante la edad moderna. Huelva, Universidad de Huelva, 2002, pp. 199-208.

Pascua, M. J. de la: «Social Reproduction and Alone Women Households: Cadiz in the 18th Century», Women, Family, Private Life and Sexuality. $4^{\text {th }}$ Conference of the International Federation for Research in Women's History. Belfast, Queen's University, 2003.

Pascua, M. J. Je la: «Women Alone in Enlightenment Spain» en Jaffe, C., Lewis, E. (Eds.): Eve's Enlightenment: Women's Experience in Spain and Spanish America, 1726-1839. Baton Rouge, Louisiana State University Press, 2009, pp. 128-142.

PAscuA, M. ${ }^{a}$ J. de la: «Madres, mujeres y solas: el oficio de vivir en la España del siglo XviII», en Franco, G. (Ed.): Debates sobre la maternidad desde una perspectiva histórica (Siglos XVI-XX). Barcelona, Icaria, 2010, pp. 231-270.

Pascua, M. J J. de la: «Violencia y familia en la España Moderna», Castellano, J. L., López-Guadalupe, M. L. (Eds.): Actas de la XI Reunión Cientifica de la Fundación Española de historia Moderna. Granada, Universidad de Granada, 2012, pp. 127-157

Pascua, M. ${ }^{a}$ J. de la: «Estrategias para el regreso sobre un mar de olvidos: Las mujeres de los ausentes en Indias ante los tribunales (1695-1804)», I Coloquio Cientifico

(C) Ediciones Universidad de Salamanca / ®®@ Stud. his., H. ${ }^{a}$ mod., 38, n. 2 (2016), pp. 237-285 


\section{MARÍA JOSÉ DE LA PASCUA SÁNCHEZ \\ «A LA SOMBRA» DE HOMBRES AUSENTES: \\ MUJERES MALCASADAS EN EL MUNDO HISPÁNICO DEL SETECIENTOS}

ANDATLAN. Andalucía en el mundo atlántico moderno: agentes y escenarios. Universidad de Sevilla (Sevilla, octubre, 2015), en prensa.

Pascua, M. ${ }^{a}$ J. de la: «Vivir en soledad, vivir en compañía: las mujeres y el mundo familiar en el siglo XVIII hispánico», GarCíA, M. R. (Ed.): El siglo XVIII en femenino. Madrid, Síntesis, 2016, pp. 147-186.

Pérez, J: Cádiz, la ciudad desnuda. Cambio económico y modelo demográfico en la formación de la Andalucía contemporánea. Cádiz, Publicaciones de la Universidad de Cádiz, 1992.

Pérez, M. J.: La familia, la casa y el convento. Las mujeres leonesas durante la edad Moderna. León, Universidad de León, 2012.

Perry, M. E.: Ni espada rota ni mujer que trota: mujer y desorden social en la Sevilla del Siglo de Oro. Barcelona, Crítica, 1993.

ReY, O.: «Les femmes seules du Nord-Ouest de l'Espagne : trajectoires féminines dans un territoire d'émigration, 1700-1860 », Annales de Démographie Historique, 2006, pp. 13-30.

Rial, S. M.: Las mujeres en la economía urbana del Antiguo Régimen: Santiago durante el siglo XVIII. Santiago de Compostela, Edicios do Castro, 1995.

RIAL, S.: «Las mujeres solas en la sociedad semi-urbana gallega del siglo XVIII», Obradoiro de Historia Moderna 8, 1999, 169-197.

Rowlands, A.: «To Wear a Virgin's Wreath: Gender and Problems of Conformity in Early Modern Germany», European Review of History, vol. 1, 1994, pp. 227-234.

RuBio, L.: «Estructuras agrarias y modelos organizativos de las comunidades campesinas leonesas durante la Edad Moderna», Melánges de la Casa de Velázquez, XXIX (2), 1993, pp. 253-274.

RuIz, M.: Matrimonio, moral sexual y justicia eclesiástica en Andalucía occidental: la Tierra Llana de Huelva (1700-1750). Sevilla, Universidad de Sevilla, 2011.

SANZ, F. F.: «Familia, hogar y vivienda en Burgos a mediados del siglo XVIII. Entre cuatro paredes, compartiendo armarios, camas, mesas y manteles», Investigaciones históricas 22, 2002, pp. 165-211.

SAlas, J. A.: «Movimientos migratorios en la España de la Edad moderna», Boletín de la $A D E H, \mathrm{VI}, 2,1988$, pp. 33-37.

Scott, J. W., Tilly, L. S.: Women, Work and Family. Nueva York, Holt-Rinehart \& Winston, 1978.

Stansell, Ch.: City of Women: Sex and Class in New York, 1789-1860. Nueva York, Knopf, 1986.

Tilly, L., Sсотт, J.: «Women's Work and the Family in Nineteenth Century Europe», Comparative Studies in Society and History, 17, 1975, pp. 36-64.

WIESNER, M. E.: «Paternalism in Practice: the Control of Servants and Prostitutes in Early Modern German Cities», en Bebb, Ph. N., Marshall, S. (Eds.): The Process of Change in Early Modern Europe. Athens, Ohio University Press, 1988, pp. 179-200.

(C) Ediciones Universidad de Salamanca / ®@ Stud. his., H. ${ }^{a}$ mod., 38, n. 2 (2016), pp. 237-285 
